\title{
The carbon and nitrogen budget of Desmophyllum dianthus - a voracious cold-water coral thriving in an acidified Patagonian fjord
}

\author{
Sandra R Maier ${ }^{\text {Corresp., } 1,2}$, Carin Jantzen ${ }^{1}$, Jürgen Laudien ${ }^{1}$, Vreni Häussermann ${ }^{3,4}$, Günter Försterra ${ }^{5}$, Astrid \\ Cornils ${ }^{1}$, Jutta Niggemann ${ }^{6}$, Thorsten Dittmar ${ }^{6,7}$, Claudio Richter ${ }^{1,8}$ \\ ${ }^{1}$ Department of Biosciences, Alfred Wegener Institute Helmholtz Center for Polar and Marine Research, Bremerhaven, Germany \\ 2 Department of Estuarine and Delta Systems, Royal Netherlands Institute for Sea Research (NIOZ-Yerseke), Yerseke, Netherlands \\ 3 Facultad de Economía y Negocios, Universidad San Sebastián, Puerto Montt, Chile \\ 4 Huinay Foundation, Puerto Montt, Chile \\ 5 Escuela de Ciencias del Mar, Facultad de Recursos Naturales, Pontificia Universidad Católica de Valparaíso, Valparaíso, Chile \\ 6 Institute for Chemistry and Biology of the Marine Environment (ICBM), University of Oldenburg, Oldenburg, Germany \\ 7 Helmholtz Institute for Functional Marine Biodiversity (HIFMB), University of Oldenburg, Oldenburg, Germany \\ 8 Department of Biology/Chemistry, University of Bremen, Bremen, Germany \\ Corresponding Author: Sandra R Maier \\ Email address: mail.maier.sandra@gmail.com
}

In the North Patagonian fjord region, the cold-water coral (CWC) Desmophyllum dianthus occurs in high densities, in spite of low pH and aragonite saturation. If and how these conditions affect the energy demand of the corals is so far unknown. In a laboratory experiment, we investigated the carbon and nitrogen $(C, N)$ budget of $D$. dianthus from Comau Fjord under three feeding scenarios: (1) live fjord zooplankton (100 - $2300 \mu \mathrm{m}),(2)$ live fjord zooplankton plus krill (> $7 \mathrm{~mm}$ ), and (3) four-day food deprivation. In closed incubations, $\mathrm{C}$ and $\mathrm{N}$ budgets were derived from the difference between $\mathrm{C}$ and $\mathrm{N}$ uptake during feeding and subsequent $\mathrm{C}$ and $\mathrm{N}$ loss through respiration, ammonium excretion, release of particulate organic carbon and nitrogen (POC, PON). Additional feeding with krill significantly increased coral respiration (35\%), excretion (131\%), and POC release (67\%) compared to feeding on zooplankton only. Nevertheless, the higher $\mathrm{C}$ and $\mathrm{N}$ losses were overcompensated by the threefold higher $\mathrm{C}$ and $\mathrm{N}$ uptake, indicating a high assimilation and growth efficiency for the krill plus zooplankton diet. In contrast, short food deprivation caused a substantial reduction in respiration (59\%), excretion (54\%), release of POC (73 $\%)$ and PON (87 \%) compared to feeding on zooplankton, suggesting a high potential to acclimatize to food scarcity (e.g. in winter). Notwithstanding, unfed corals 'lost' $2 \%$ of their tissue-C and $1.2 \%$ of their tissue- $\mathrm{N}$ per day in terms of metabolism and released particulate organic matter (likely mucus). To balance the $\mathrm{C}(\mathrm{N})$ losses, each $D$. dianthus polyp has to consume around 700 (400) zooplankters per day. The capture of a single, 
large krill individual, however, provides enough $\mathrm{C}$ and $\mathrm{N}$ to compensate daily $\mathrm{C}$ and $\mathrm{N}$ losses and grow tissue reserves, suggesting that krill plays an important nutritional role for the fjord corals. Efficient krill and zooplankton capture, as well as dietary and metabolic flexibility, may enable $D$. dianthus to thrive under adverse environmental conditions in its fjord habitat; however, it is not known how combined anthropogenic warming, acidification and eutrophication jeopardize the energy balance of this important habitat-building species. 


\section{The carbon and nitrogen budget of}

2 Desmophyllum dianthus - a voracious cold-water

3 coral thriving in an acidified Patagonian fjord

4

5

6

Sandra R. Maier ${ }^{1,2}$, Carin Jantzen ${ }^{1}$, Jürgen Laudien ${ }^{1}$, Vreni Häussermann ${ }^{3,4}$, Günter Försterra ${ }^{5}$, Astrid Cornils ${ }^{1}$, Jutta Niggemann ${ }^{6}$, Thorsten Dittmar ${ }^{6,7}$, Claudio Richter ${ }^{1,8}$

${ }^{1}$ Department of Biosciences, Alfred Wegener Institute Helmholtz Center for Polar and Marine Research, Bremerhaven, Germany

${ }^{2}$ Department of Estuarine and Delta Systems, Royal Netherlands Institute for Sea Research (NIOZ-Yerseke), Yerseke, Netherlands

${ }^{3}$ Facultad de Economía y Negocios, Universidad San Sebastián, Puerto Montt, Chile

${ }^{4}$ Huinay Foundation, Puerto Montt, Chile

${ }^{5}$ Escuela de Ciencias del Mar, Facultad de Recursos Naturales, Pontificia Universidad Católica de Valparaíso, Valparaíso, Chile

${ }^{6}$ Institute for Chemistry and Biology of the Marine Environment (ICBM), University of Oldenburg, Oldenburg, Germany

${ }^{7}$ Helmholtz Institute for Functional Marine Biodiversity (HIFMB), University of Oldenburg, Oldenburg, Germany

${ }^{8}$ Department of Biology/Chemistry, University of Bremen, Bremen, Germany

Corresponding Author:

Sandra Maier ${ }^{1,2}$

Korringaweg 7, 4401 NT Yerseke, Netherlands

Email address: mail.maier.sandra@gmail.com

\section{Abstract}

In the North Patagonian fjord region, the cold-water coral (CWC) Desmophyllum dianthus occurs in high densities, in spite of low $\mathrm{pH}$ and aragonite saturation. If and how these conditions affect the energy demand of the corals is so far unknown. In a laboratory experiment, we investigated the carbon and nitrogen $(\mathrm{C}, \mathrm{N})$ budget of $D$. dianthus from Comau Fjord under three feeding scenarios: (1) live fjord zooplankton $(100-2300 \mu \mathrm{m})$, (2) live fjord zooplankton plus krill (> $7 \mathrm{~mm}$ ), and (3) four-day food deprivation. In closed incubations, $\mathrm{C}$ and $\mathrm{N}$ budgets were derived from the difference between $\mathrm{C}$ and $\mathrm{N}$ uptake during feeding and subsequent $\mathrm{C}$ and $\mathrm{N}$ loss through respiration, ammonium excretion, release of particulate organic carbon and nitrogen (POC, PON). Additional feeding with krill significantly increased coral respiration (35\%), excretion (131\%), and POC release (67\%) compared to feeding on zooplankton only.

Nevertheless, the higher $\mathrm{C}$ and $\mathrm{N}$ losses were overcompensated by the threefold higher $\mathrm{C}$ and $\mathrm{N}$ 
40 uptake, indicating a high assimilation and growth efficiency for the krill plus zooplankton diet. In 41 contrast, short food deprivation caused a substantial reduction in respiration (59\%), excretion

42 (54\%), release of POC (73\%) and PON (87\%) compared to feeding on zooplankton, suggesting 43 a high potential to acclimatize to food scarcity (e.g. in winter). Notwithstanding, unfed corals

44 'lost' $2 \%$ of their tissue-C and $1.2 \%$ of their tissue-N per day in terms of metabolism and 45 released particulate organic matter (likely mucus). To balance the $\mathrm{C}(\mathrm{N})$ losses, each D. dianthus 46 polyp has to consume around 700 (400) zooplankters per day. The capture of a single, large krill 47 individual, however, provides enough $\mathrm{C}$ and $\mathrm{N}$ to compensate daily $\mathrm{C}$ and $\mathrm{N}$ losses and grow 48 tissue reserves, suggesting that krill plays an important nutritional role for the fjord corals. 49 Efficient krill and zooplankton capture, as well as dietary and metabolic flexibility, may enable 50 D. dianthus to thrive under adverse environmental conditions in its fjord habitat; however, it is 51 not known how combined anthropogenic warming, acidification and eutrophication jeopardize 52 the energy balance of this important habitat-building species.

53

54

55

\section{Introduction}

Corals are ecosystem engineers (Jones, Lawton \& Shachak, 1994), forming reefs and other 'marine animal forests' (Rossi et al., 2017), that are amongst the most diverse ecosystems on Earth (Jones \& Endean, 1973; Henry \& Roberts, 2016). As calcifying organisms, scleractinian corals are vulnerable to anthropogenically-caused ocean acidification (Cohen \& Holcomb, 2009). Increased atmospheric carbon dioxide dissolves in seawater, where it decreases the $\mathrm{pH}$ (Caldeira $\&$ Wickett, 2003) and the saturation state of aragonite, a crystal form of calcium carbonate (Turley, Roberts \& Guinotte, 2007). Since corals form aragonite skeletons, ocean acidification affects their calcification and skeletal growth (Cohen \& Holcomb, 2009; Hennige et al., 2015; Büscher, Form \& Riebesell, 2017). To maintain calcification under these conditions, the corals may up-regulate their internal pH (Trotter et al., 2011; Anagnostou et al., 2012; McCulloch et al., 2012), but this is an energy-costly process requiring a corresponding energy supply (Gattuso, Allemand \& Frankignoulle, 1999; Cohen \& Holcomb, 2009). Accordingly, experimental studies have suggested that enhanced heterotrophic feeding could partially counteract the negative impact of ocean acidification on coral calcification (Cohen \& Holcomb, 2009; Georgian, Shedd \& Cordes, 2014; Martínez-Dios et al., 2020).

Cold-water corals (CWCs) form one of the most structurally-complex habitats of the deep sea (Roberts, Wheeler \& Freiwald, 2006), but occur also in shallower waters of temperate fjords (Freiwald et al., 2004). Since aragonite saturation is lower in the deep and cold (Chen, Feely \& Gendron, 1988; Jiang et al., 2015), scleractinian CWCs are considered particularly vulnerable to ocean acidification (Turley, Roberts \& Guinotte, 2007). Most CWC ecosystems are predicted to experience aragonite undersaturation by 2100 (Guinotte et al., 2006; Zheng \& Cao, 2014). Nevertheless, in the North Patagonian Comau Fjord (Los Lagos Region, Chile; Fig. 1), the scleractinian CWC species Desmophyllum dianthus thrives under low pH (7.4-8.4), near and below aragonite saturation ( $\Omega_{\text {aragonite }} 0.9$ to 1.6; Fillinger \& Richter, 2013; Jantzen et al., 2013a). 
80 The low $\mathrm{pH}$ may relate to the high organic matter concentration from high productivity in the

81

82

83

84

85

86

87

88

89

90

91

92

93

94

95

96

97

98

99

100

101

102

103

104

105

106

107

108

109

110

111

112

113

114

115

116

117

118

119 area (Montero et al., 2011) and terrestrial run-off to the fjord (Försterra \& Häussermann 2003, Jantzen et al. 2013a). The naturally low aragonite saturation state provides a rare opportunity to study the food demand of a CWC under geochemical conditions, which most CWCs will face by the end of the century (Försterra, Häussermann \& Laudien, 2016).

Desmophyllum dianthus is a solitary, ahermatypic (not reef-building) CWC species with a cosmopolitan distribution (Försterra \& Häussermann, 2003; Cairns, Häussermann \& Försterra, 2005). In Comau Fjord, the species forms vast coral banks between 20 and $280 \mathrm{~m}$ water depth, particularly on steep, partly overhanging walls (Försterra \& Häussermann, 2003; Fillinger \& Richter, 2013; Försterra et al., 2016). Their sheltered occurrence, in an upside-down position under overhangs, has been interpreted as avoidance to sedimentation (Försterra \& Häussermann, 2003). Though ahermatypic, a diverse benthic community is (facultatively) associated with the coral banks, including sponges, bryozoans, tube-forming polychaetes, anthozoans, and bivalves (Försterra et al., 2005; Försterra, Häussermann \& Laudien, 2016). Further, D. dianthus from the shallow parts of Comau Fjord typically has live tissue only on the apical end of the corallum (skeleton), while the basal end is bare and provides a settlement substrate (habitat) for various epibiontic and endolithic organisms, e.g. foraminiferans, bio-eroding sponges, and photoautotrophic microorganisms (Försterra et al., 2005; Hassenrück et al., 2013).

The natural conditions of low $\mathrm{pH}$ and relatively high turbidity in the fjord region are exacerbated by climate change and intense salmon aquaculture (Buschmann et al., 2009; Mayr et al., 2014; Iriarte, 2018). It is therefore important to (1) know the energetic costs involved in coping with present and future fjord environments (low $\mathrm{pH}$, high turbidity) and (2) estimate the resilience to disturbance affecting the energy budget, growth and reproduction of these ecosystem engineers (Melzner et al., 2009; Findlay et al., 2011; Vidal-Dupiol et al., 2013). The energy budget of the fjord corals, i.e. their food supply against energetic costs, is presently unknown. The carbon and nitrogen isotopic composition of $D$. dianthus from Comau Fjord indicates mostly consumption of zooplankton (Mayr et al., 2011). With its large polyps (up to $6 \mathrm{~cm}$ in diameter, Försterra \& Häussermann 2003), D. dianthus is able to capture not only mesozooplankton (0.2-2 mm length), such as copepods, but also larger micronekton, such as euphausiids (krill) (Sokol, 2012; Höfer et al., 2018). To fuel its respiratory carbon demand, D. dianthus from the Mediterranean deep sea requires the equivalent of three adult brine shrimps (Artemia salina) per day (Naumann et al., 2011). However, A. salina does not occur in the coral habitat and feeding on natural prey may entail a different carbon budget (Møller \& Riisgård, 2007). In the North Patagonian fjord region, the zooplankton abundance shows a pronounced seasonality, with a maximum following the spring phytoplankton bloom and a minimum in Austral winter (Iriarte et al., 2007; González et al., 2010). In experiments, increased availability of zooplankton food enhanced the skeletal growth of the fjord corals (Martínez-Dios et al., 2020), but it is unknown whether food is currently limiting coral growth in the fjord region. 
120

121

122

123

124

125

126

127

128

129

130

131

132

133

134

135

136

137

\section{8}

139

140

141

142

143

144

145

146

147

148

149

150

151

152

153

154

155

156

157

158

159

Here, we investigate the carbon and nitrogen $(\mathrm{C}$ and $\mathrm{N})$ budget of the $\mathrm{CWC}$ D. dianthus under present-day low-pH conditions in Comau Fjord, Chile, i.e. the difference between $\mathrm{C}$ and $\mathrm{N}$ uptake and $\mathrm{C}$ and $\mathrm{N}$ loss (Fig. 2). CWCs release the indigestible parts of their food and coral mucus (Wild et al., 2008) as particulate and dissolved organic matter (POM, DOM), measurable as particulate and dissolved organic carbon and nitrogen (POC, PON; DOC, DON). CWC metabolism involves oxygen consumption and carbon dioxide production through respiration, as well as ammonium production via excretion (Khripounoff et al., 2014; Maier et al., 2019). The remaining, non-released $\mathrm{C}$ and $\mathrm{N}$ is available for growth of somatic and reproductive tissue and therefore termed 'scope for growth' (Warren \& Davis 1967). Since C and N uptake and loss typically depend on meal size and quality (Secor, 2008), we determined the $\mathrm{C}$ and $\mathrm{N}$ budget (uptake versus loss) of the fjord corals under three different feeding scenarios, simulating the varying zooplankton availability in the fjord region (Iriarte et al., 2007; González et al., 2010): (1) live fjord zooplankton $(100-2300 \mu \mathrm{m})$, (2) live fjord zooplankton plus larger krill $(>7 \mathrm{~mm})$, and (3) short-term food deprivation. From these budgets, we estimated the minimum $\mathrm{C}, \mathrm{N}$ and zooplankton demand of $D$. dianthus in the North Patagonian fjord region and evaluated the scope for growth of this habitat-forming CWC species.

\section{Materials \& Methods}

\section{Coral collection and maintenance}

Thirteen similar-sized $D$. dianthus specimens (calyx height: $3.4 \pm 0.4 \mathrm{~cm}$, calyx length: $1.4 \pm 0.2 \mathrm{~cm}$, calyx width: $2 \pm 0.4 \mathrm{~cm}$, Fig. $3 \mathrm{~A}$ ) were collected live from $20 \mathrm{~m}$ water depth in Comau Fjord (Cross Huinay, Liliguapi, Fig. 1) in January 2012. The collection of D. dianthus for scientific purposes was approved by the Chilean Ministry of Economy, Development \& Tourism, sub-secretariat of fisheries and farming (ref. 1742). The corals were chiseled off the substrate by SCUBA divers and immediately placed into water-tight, sealed plastic containers, ensuring no contact with either the brackish surface water layer or air during transport to the laboratory. To remove epibiontic and endolithic organisms (Försterra \& Häussermann, 2003), the bare corallum was carefully cut off with a submerged diamond blade (3.2 mm thick), connected to an electric grinder (Jantzen et al. 2013b). The fracture zone was sealed with cyano-acrylate gel (super flex glue gel) and glued to a polyethylene screw (Jantzen et al., 2013b), which served to fix the corals in their natural 'upside-down' growth position (Fig. 3A).

For maintenance before and during the experiment, corals were kept in three $28 \mathrm{~L}$-maintenance tanks (Fig. 3A, maximum seven corals per tank) with a flow-through of $10 \mu \mathrm{m}$ - filtered fjord water, continuously pumped from $25 \mathrm{~m}$ depth off Huinay (flow: $4.2 \mathrm{~L} \mathrm{~h}^{-1}$; temperature: $11.9^{\circ} \mathrm{C}$; salinity: 31.6; particulate organic matter concentration: $12.8 \pm 4.2 \mu \mathrm{mol} \mathrm{POC} \mathrm{L}{ }^{-1} ; 1.4 \pm 1.2 \mu \mathrm{mol}$ PON L ${ }^{-1}$ ). Before the start of the experiment, corals were fed for two hours per day with $1 / 4$ of a haul of live, freshly-collected fjord zooplankton (see next section). This corresponds to a zooplankton concentration of $571 \pm 203$ zooplankton individuals $\mathrm{L}^{-1}$ (mean \pm standard deviation),

Peer) reviewing PDF | (2021:07:63798:1:1:NEW 11 Nov 2021) 
160

161

162

163

164

165

166

167

168

169

170

171

172

173

174

175

176

177

178

179

180

181

182

183

184

185

186

187

188

189

190

191

192

193

194

195

196

197

198

199

equivalent to $85 \pm 30 \mu \mathrm{mol} \mathrm{C} \mathrm{L} \mathrm{C}^{-1}$ and $16 \pm 6 \mu \mathrm{mol} \mathrm{N} \mathrm{L}$, as analyzed in four additional aliquots of 1/4 of a zooplankton haul (see section 'Sample analysis'). During feeding, water exchange was interrupted.

Before the start of the experiment, all corals were weighed in seawater of ambient temperature and salinity (density $1.026 \mathrm{~g} \mathrm{~cm}^{-3}$ ) with an analytical balance equipped with an underfloor weighing basket (Sartorius CPA225DOCE). Polyp dry mass was derived from buoyant weight according to Davies (1989), using a species-specific aragonite density of $2.835 \mathrm{~g} \mathrm{~cm}^{-3}$ (Naumann et al., 2011). Corals were given a recovery and acclimatization time of three weeks from collection and preparation to the start of the experiment.

\section{Zooplankton and krill collection}

Live fjord zooplankton was collected ca. $1 \mathrm{~km}$ off the Huinay Scientific Field Station (Fig. 1) every afternoon, by a single vertical haul from $20 \mathrm{~m}$ water depth with a $100 \mu \mathrm{m}-\mathrm{Nansen}$ net (diameter $0.7 \mathrm{~m}$ ). The size range of individual zooplankters (100-2300 $\mu \mathrm{m}$ maximum extension) was measured under the binocular on three subsamples. To feed the corals in their maintenance tanks (previous section), the zooplankton haul was split with a Motoda plankton sample splitter into equal 1/4 portions. To feed the corals with zooplankton as part of the experimental feeding treatments (see below), the respective zooplankton haul was split into equal 1/8 portions, which were split again with measurement cylinders into ten equal portions (1/80 of the original haul).

Krill (euphausiids, i.e. Euphausia vallentini, adult and pre-adult stages) were collected at night in Comau Fjord between 20 and $80 \mathrm{~m}$ water depth, in a 45-min horizontal trawl at 2 knots with a ring trawl net $(0.5 \mathrm{~m}$ diameter, $500 \mu \mathrm{m}$ mesh size $)$. Krill were drained on paper tissue, measured (cephalo-thoracic length, ca. $7 \mathrm{~mm})$, weighed (wet mass) and stored frozen $\left(-13^{\circ} \mathrm{C}\right)$ until utilization in the experiment (see below). Six euphausiids were dried ( $40{ }^{\circ} \mathrm{C}$, three days), weighed again (dry mass, $3.3 \pm 1.5 \mathrm{mg}$ ) and used for $\mathrm{C}$ and $\mathrm{N}$ analysis (see below).

\section{Experimental design}

This section focuses on the experimental design, as shown in Fig. 4, while experimental set-up, feeding and incubations are detailed in the following sections. A detailed chronology of the experiment is provided in Supplemental Table 1.1.

To determine the $\mathrm{C}$ and $\mathrm{N}$ budget of $D$. dianthus, we designed a two-batch repeated-measures laboratory experiment with in total three different feeding scenarios (Fig. 4). This experimental design was chosen to simulate the temporally variable food availability in Comau Fjord (see Introduction). Both coral batches were initially offered live fjord zooplankton (Fig. 4, feeding scenario 'zooplankton'), which presumably corresponds to the natural 'baseline' food situation in the field (Mayr et al., 2011). Batch I ( $\mathrm{n}=6$ corals) was subsequently offered a surplus of food, i.e. zooplankton plus krill (feeding scenario 'zooplankton+krill', see below), while batch II ( $\mathrm{n}=7$ 
200

201

202

203

204

205

206

207

208

209

210

211

212

213

214

215

216

217

218

219

220

221

222

223

224

225

226

227

228

229

230

231

232

233

234

235

236

237

238

239

corals) remained unfed, mimicking food (zooplankton) shortage, e.g. in winter (feeding scenario 'unfed', see below). Within each batch, at least two $\mathrm{C}$ and $\mathrm{N}$ budgets were determined separately for each individual coral, by repeated measurements on the same specimens (Fig. 4). To determine the $\mathrm{C}$ and $\mathrm{N}$ budgets, we first measured the $\mathrm{C}$ and $\mathrm{N}$ uptake of each individual coral from food during the respective feeding treatments (Fig. 4). Secondly, after each feeding treatment, the corals were individually incubated without food for 9-11 h (Fig. 4), to measure their $\mathrm{C}$ and $\mathrm{N}$ loss in terms of $\mathrm{C}$ respiration, ammonium excretion, and release of $\mathrm{POC}, \mathrm{PON}$, DOC, DON (Fig. 2). In between the different feeding scenarios (Fig. 4), the corals were kept in their maintenance tanks and fed daily with live fjord zooplankton (see section 'Coral collection and maintenance'), for re-acclimatization to natural 'baseline' feeding conditions. Ideally, experimental corals should have been kept separate throughout the entire experiment, to ensure full independence of the replicates, but this was not possible for logistic reasons. Instead, each coral batch was split into subsets of one to three corals, which were distributed over three maintenance tanks. Different coral subsets within the batches were kept in different maintenance tanks and tank position was shuffled during the experiment, to achieve a partial independence of coral replicates within the batches (Supplemental Table 1.1) and to minimize the odds of a differential tank effect between the batches. Experimental feeding treatments and incubations (including measurements of $\mathrm{C}$ and $\mathrm{N}$ fluxes) were done in separate experimental bottles (see section 'Experimental set-up') to ensure independence of the results.

In the 'zooplankton' feeding scenario (Fig. 4, both batches), the corals were fed with live fjord zooplankton (1025 \pm 332 zooplankters $\left.\mathrm{L}^{-1}\right)$ in separate experimental bottles for $2 \mathrm{~h}$ (Fig. 3B; for details, see section 'Feeding with zooplankton and krill'). Such short pulses of high zooplankton availability may occur when a zooplankton swarm with high individual densities (Ambler, 2002) is advected by local currents (3-11 $\mathrm{cm} \mathrm{s}^{-1}$, Jantzen et al. 2013b). Zooplankton swarms are common in fjord boundaries (Hirche, Laudien \& Buchholz, 2016). The 9-11 h-incubations in separate experimental bottles (called 'zoopl') followed 2-3 $\mathrm{h}$ after feeding on zooplankton (for details, see section 'Incubations'); hence, $\mathrm{C}$ and $\mathrm{N}$ losses were measured between 2-14 h after feeding, covering the time it takes tropical scleractinian corals to digest zooplankton (Sebens et al., 1996; digestion times of CWCs are unknown). In the 'zooplankton+krill' feeding scenario (Fig. 4), the corals were additionally fed with one individual euphausiid, 3-4 h after receiving live fjord zooplankton. Taking into account the larger food ration and the presumably prolonged digestion time, we here carried out two 9-11 h-incubations, the first starting $1 \mathrm{~h}$ after feeding on krill (covering the period between 1-12 h after feeding, called 'krill.d1'), the second starting $24 \mathrm{~h}$ after feeding on krill (covering the period between 24-35 $\mathrm{h}$ after feeding, called 'krill.d2'). In between the incubations 'krill.d1' and 'krill.d2', the corals remained unfed. In the 'unfed' scenario (Fig. 4), corals remained unfed in their maintenance tank (10 $\mu \mathrm{m}$-filtered seawater; all corals in one tank) for four days. After this period, corals were incubated once for 9-11 h (incubation called 'unfed'). 


\section{Experimental set-up}

241 Feeding with zooplankton and krill, and incubations, were carried out at $11^{\circ} \mathrm{C}$ (representing in

242 situ temperature) in separate experimental bottles with one coral each (Fig. 3B, C). As

243 experimental bottles, we used SCHOTT-DURAN ${ }^{\circledR}$ bottles of $0.5 \mathrm{~L}$ specified volume, which fit a 244 total volume of $0.8 \mathrm{~L}$ (including the bottleneck). The bottles were filled with $10 \mu \mathrm{m}$-filtered fjord 245 water, pumped from $25 \mathrm{~m}$ depth off Huinay. The coral was fixed in its natural 'upside-down' 246 position (Fig. 3B, C) in the custom-built bottle lid (Jantzen et al., 2013b). A magnetic stirring bar 247 at the bottle floor created a circular flow of $\sim 1 \mathrm{~cm} \mathrm{~s}^{-1}$; to estimate this flow, we filmed the 248 particle movement in unfiltered seawater from above, stopped the time that the circulating 249 particles needed to cross sections of known length at different orbits of the bottle, and averaged 250 the resulting flow velocities (distance/time). The flow was high enough to kept live zooplankton 251 in suspension, but low enough not to bend the coral tentacles (Sokol, 2012).

252

\section{Feeding with zooplankton and krill}

The feeding scenarios 'zooplankton' and 'zooplankton+krill' (Fig. 3B) were started by adding one aliquot of live zooplankton food (1/80 of one zooplankton haul in $50 \mathrm{~mL}$ filtered seawater) to each of the experimental bottles. For each zooplankton-fed coral subset (Supplemental Table 1.1), five additional aliquots of live zooplankton food were prepared the same way and analyzed for the amount of POC and PON ( $\mathrm{n}=3)$ and the number of zooplankton individuals $(\mathrm{n}=2)$ added to each experimental bottle (Fig. 3B: 'start POC, PON, zooplankton'). In the feeding scenario 'zooplankton+krill', zooplankton food aliquots were analyzed for POC and PON (n=3), but not for zooplankton. Start POC and PON concentrations in the feeding scenario 'zooplankton' were $164 \pm 36 \mu \mathrm{mol} \mathrm{C} \mathrm{L}{ }^{-1}$ and $30 \pm 7 \mu \mathrm{mol} \mathrm{N} \mathrm{L}^{-1}$, start POC and PON concentrations in the feeding scenario 'zooplankton+krill' were $126 \pm 0.3 \mu \mathrm{mol} \mathrm{C} \mathrm{L}^{-1}$ and $24 \pm 0.1 \mu \mathrm{mol} \mathrm{N} \mathrm{L}{ }^{-1}$. The start zooplankton concentration was $1025 \pm 332$ zooplankters $\mathrm{L}^{-1}$ in the feeding scenario 'zooplankton' (mean \pm standard deviation; averaged over all replicates); the start zooplankton concentration in the feeding scenario 'zooplankton+krill' was presumably similar. Per coral subset (Supplemental Table 1.1), triplicate seawater controls were prepared (Fig. 3B: 'control'); these were experimental bottles without corals, but with zooplankton food, that served to determine zooplankton loss from internal zooplankton predation and handling. During feeding, polyp activity was closely monitored, to ensure that all corals had their tentacles expanded. To end the feeding after $2 \mathrm{~h}$, the corals were removed from the bottles and returned to the maintenance tanks. Control incubations (seawater only) were ended with $0.5-1 \mathrm{~h}$ delay (i.e.

274

275 $\mathrm{t}=2.5-3 \mathrm{~h}$ ), due to logistical limitations (handling time). Due to the low activity in the seawateronly controls, we expect no significant bias related to the longer duration. End water samples for the amount of POC and PON (290-370 mL) and for the number of zooplankton individuals (350276 $490 \mathrm{~mL}$; only in feeding scenario 'zooplankton') were taken from each experimental bottle after thorough mixing (Fig. 3B, 'end POC, PON, zooplankton'). POC and PON samples were

278 279 collected on pre-combusted $\left(24 \mathrm{~h}, 50{ }^{\circ} \mathrm{C}\right)$, pre-weighed $0.7 \mu \mathrm{m}$ - glass-fiber filters $(\mathrm{GF} / \mathrm{F})$ by vacuum filtration. Filters were frozen $\left(-13^{\circ} \mathrm{C}\right)$ and dried to constant mass at $40{ }^{\circ} \mathrm{C}$. Zooplankton 
280

281

282

283

284

285

286

287

288

289

290

291

292

293

294

295

296

297

298

299

300

301

302

303

304

305

306

307

308

309

310

311

312

313

314

315

316

317

318

319

samples were concentrated over a $55 \mu \mathrm{m}$-mesh and fixed in $4 \%$-borax-buffered formaldehyde. For feeding with krill (in the feeding scenario 'zooplankton+krill'), the corals were returned to the separate experimental bottles 3-4 h after feeding on zooplankton and received one thawed, pre-measured euphausiid via tweezers (Fig. 3B).

\section{Incubations}

For the incubations (without food), the corals were placed into the experimental (SCHOTT) bottles, that were filled with $10 \mu \mathrm{m}$-filtered fjord water and closed air bubble-free with a lid (Fig. 3C). Per coral subset (Supplemental Table 1.1), we additionally prepared triplicate seawater controls without corals (Fig. 3C: 'control') to determine the possible effect of nano- and picoplankton oxygen $\left(\mathrm{O}_{2}\right), \mathrm{C}$ and $\mathrm{N}$ fluxes on our results. At the start of the incubation, the start $\mathrm{O}_{2}$ concentration was measured with an optode (HQ40d; Hach, USA; resolution: $0.1 \mathrm{mg} \mathrm{O}_{2} \mathrm{~L}^{-1}$ ) in a separate experimental bottle $\mathrm{B}_{\mathrm{o}}$ ('start $\mathrm{O}_{2}{ }^{\prime}$ ). Start water samples were taken by syringe from $\mathrm{B}_{\mathrm{o}}$ for analysis of dissolved inorganic nitrogen (DIN, i.e. ammonium, nitrate, nitrite; $100 \mathrm{~mL}$ ), DOC, and DON (20 mL, in triplicates). The remaining water in $\mathrm{B}_{\mathrm{o}}(300-600 \mathrm{~mL})$ was used for POC and PON analysis. During the incubation, coral polyps remained protruded with extended tentacles. At the end of the incubation, the corals were removed and returned to their maintenance tanks. In each experimental bottle, the end $\mathrm{O}_{2}$ concentration was first measured, before taking end water samples for DIN, DOC, DON, POC and PON. The end $\mathrm{O}_{2}$ concentration was never below $80 \%$ of the start $\mathrm{O}_{2}$ concentration, a conservative threshold to avoid effects of low-oxygen concentration on coral physiology (Dodds et al., 2007). DIN samples were filtered through GF/F-filters into glass vials and fixed with a concentrated mercury chloride solution $\left(0.105 \mathrm{~g} \mathrm{~L}^{-1}\right)$ to prevent microbial activity. Samples for DOC and DON were filtered through $\mathrm{GF} / \mathrm{F}$-filters into glass vials (filters and vials pre-combusted, $450{ }^{\circ} \mathrm{C}, 12 \mathrm{~h}$ ), acidified to $\mathrm{pH}=2$ with $32 \%$ hydrochloric acid to avoid microbial activity and stored dark at $4{ }^{\circ} \mathrm{C}$. Sample processing for POC and PON was described in the previous section ('Feeding').

\section{Coral tissue sampling}

At the end of the experiment, the coral tissue was removed from the skeleton with an airbrush filled with $0.7 \mu \mathrm{m}$-filtered seawater and homogenized with an ultra turrax (Jantzen et al., 2013c). The volume of the tissue-seawater suspension was measured. Subsamples of the tissue-seawater suspension $\left(1 \mathrm{~mL}, \mathrm{n}=6\right.$ aliquots per coral) were collected on pre-combusted $\left(500{ }^{\circ} \mathrm{C}, 24 \mathrm{~h}\right)$, preweighed GF/F-filters and dried up to constant mass at $40^{\circ} \mathrm{C}$. Coral samples were transported to Germany under CITES permit E-00427/12.

\section{Sample analyses}

Samples of coral tissue, krill, POC and PON were weighed for dry mass and subsequently analyzed for organic carbon (OC) and organic nitrogen $(\mathrm{ON})$ content on an elemental analyzer (EuroEA3000, EuroVector) with acetanilide calibration (measurement precision $>99 \%$, i.e. $<1 \%$ relative standard deviation for triplicate measurement of acetanilide). To measure the OC 
320

321

322

323

324

325

326

327

328

329

330

331

332

333

334

335

336

337

338

339

340

341

342

343

344

345

346

347

348

349

350

351

352

353

354

355

356

357

358

content of coral tissue (tissue-C), subsamples on $\mathrm{GF} / \mathrm{F}$ filters ( $\mathrm{n}=3$ per coral) were vaporacidified with $12 \mathrm{~N}$-hydrochloric acid prior to analysis, to remove remainders of skeletal inorganic carbon (Hedges \& Stern, 1984). The ON content of coral tissue (tissue-N) was measured on separate subsamples $(\mathrm{n}=3)$ without acidification. The total tissue- $\mathrm{C}$ and $-\mathrm{N}$ content of each coral was calculated by multiplying the $\mathrm{OC}$ and $\mathrm{ON}$ content measured in the subsamples $(1 \mathrm{~mL})$ with the volume of the tissue-seawater suspension (see previous section). Samples of krill, POC and PON (from feeding and incubations) were not acidified, as previous tests revealed negligible amounts of inorganic carbon. POC concentration was determined as POC $\left[\frac{\mu \mathrm{mol} C}{L}\right]=$ $\frac{P O C \text { content } G F / F \text { filter }}{\text { filtered volume }}$ PON concentration was calculated accordingly. For krill, we determined the relation between wet mass and $\mathrm{C}$ content $\left(\mathrm{C}\right.$ content $\left[\mu \mathrm{mol} \mathrm{C}\right.$ euphausiid $\left.{ }^{-1}\right]=3.9 \cdot$ wet mass $[\mathrm{mg}]$ $\left.+48.3 ; \mathrm{R}^{2}=0.86\right)$ and the relation between wet mass and $\mathrm{N}$ content $(\mathrm{N}$ content $[\mu \mathrm{mol} \mathrm{N}$ euphausiid $\left.^{-1}\right]=0.9 \cdot$ wet mass $\left.[\mathrm{mg}]+11.4 ; \mathrm{R}^{2}=0.87\right)$. Zooplankton samples were counted in a Bogorov chamber under a stereo microscope. Only undamaged, non-gelatinous zooplankters were counted.

Ammonium $\left(\mathrm{NH}_{4}^{+}\right)$, nitrate and nitrite concentration was analyzed spectrophotometrically at the ICBM-Terramare Wilhelmshaven according to Grasshoff et al. (1983) (measurement resolution: $0.01 \mu \mathrm{mol} \mathrm{N} \mathrm{L}{ }^{-1}$ ). DOC and total dissolved nitrogen (TDN) concentration was quantified via high-temperature catalytic oxidation (HTCO, Sugimura \& Suzuki 1988) on a Shimadzu TOC$\mathrm{VcpH}$ analyzer, equipped with a Total Nitrogen Measuring Unit (TNM-1), with L-arginine calibration. Analytical accuracy and precision were determined by analyzing reference samples (D. Hansell, University of Miami, USA) and were higher than $95 \%$. The datasets of DOC and TDN concentrations contained a few extreme values, possibly due to sample contamination during handling and processing. Therefore, outliers of DOC and TDN concentration were identified as values $<\mathrm{Q} 1-\mathrm{IQR} \cdot 1.5$ and values $>\mathrm{Q} 3+\mathrm{IQR} \cdot 1.5$, where Q1 was the first quartile of the data subset, Q3 the third quartile, and IQR the interquartile range between Q1 and Q3; data subsets were end values of coral incubations, end values of control incubations, and start values of coral and control incubations together. Outliers were excluded and the remaining start and end values of each incubation (samples taken in triplicate) were averaged. DON concentration was obtained as DON $=\mathrm{TDN}-\mathrm{DIN}$, with $\mathrm{DIN}=$ ammonium + nitrate + nitrite.

\section{Carbon and nitrogen budget}

For each feeding scenario, the $\mathrm{C}$ and $\mathrm{N}$ budgets of the corals were determined as the difference between $\mathrm{C}$ and $\mathrm{N}$ uptake, measured during the feeding treatment, and $\mathrm{C}$ and $\mathrm{N}$ loss, measured in the subsequent incubation (Fig. 2, 4). In the feeding scenario 'zooplankton+krill', two incubations followed the feeding treatment, hence two $\mathrm{C}$ and $\mathrm{N}$ budgets were determined per coral, one covering the period 1-12 $\mathrm{h}$ after feeding, called 'krill.d1', the second covering the period 24-35 h after feeding, called 'krill.d2' (Fig. 4). 
359

360

361

362

363

364

365

366

367

368

369

370

371

372

373

374

375

376

377

378

379

380

381

382

383

384

385

386

387

388

389

390

391

392

393

394

395

396

All $\mathrm{C}, \mathrm{N}$, and $\mathrm{O}_{2}$ fluxes were calculated from the difference between the measurement at the start of the feeding or incubation and the measurement at the end of the feeding or incubation, in coral ('coral') and seawater-control ('control') trials. The (total) $\mathrm{C}$ uptake of the corals from

zooplankton (treatments 'zooplankton', 'zooplankton+krill', in $\mu \mathrm{mol} \mathrm{C}$ ) was determined as

C uptake $=\frac{[P O C]_{\text {start, coral }}-[P O C]_{\text {end, coral }}}{t_{\text {coral }}}-\frac{[P O C]_{\text {start, control }}-[P O C]_{\text {end, control }}}{t_{\text {control }}} \cdot V \cdot t_{\text {coral }}$,

where $[\mathrm{POC}]$ is the POC concentration, $\mathrm{t}$ is the feeding time and $\mathrm{V}$ is the water volume of the coral incubation (experimental bottle volume - coral volume). The $\mathrm{N}$ uptake of the corals from zooplankton was determined similarly. In the feeding treatment 'zooplankton+krill', the total C or $\mathrm{N}$ uptake is the sum of zooplankton-C or $-\mathrm{N}$ uptake and the $\mathrm{C}$ or $\mathrm{N}$ content of the krill individual provided to the respective coral; the $\mathrm{C}$ and $\mathrm{N}$ content of the individual euphausiid was estimated from its wet mass (see previous section). In the feeding treatment 'unfed', a zero C and $\mathrm{N}$ uptake was assumed. In all feeding treatments, the $\mathrm{C}$ and $\mathrm{N}$ uptake was treated as daily rates (i.e. $\mu \mathrm{mol} \mathrm{C}$ and $\mathrm{N} \mathrm{d}^{-1}$ ), because the corals were fed once per day only. In treatment 'zooplankton', we additionally determined the zooplankton capture of the corals, as Zooplankton capture $=\frac{\text { zoopl }_{\text {start,coral }}-\text { zoopl }_{\text {end,coral }}}{t_{\text {coral }}}-\frac{\text { zoopl }_{\text {start,control }}-\text { zoopl }_{\text {end,control }}}{t_{\text {control }}} \cdot V \cdot t_{\text {coral }}$,

where zoopl is the number of zooplankton individuals.

Hourly respiration rates of the corals (in $\mu \mathrm{mol} \mathrm{O}_{2} \mathrm{~h}^{-1}$ ) were derived as

$\operatorname{Respiration}\left(\mathrm{O}_{2}\right)=\frac{\left[\mathrm{O}_{2}\right]_{\text {start,coral }}-\left[\mathrm{O}_{2}\right]_{\text {end,coral }}}{t_{\text {coral }}}-\frac{\left[\mathrm{O}_{2}\right]_{\text {start,control }}-\left[\mathrm{O}_{2}\right]_{\text {end,control }}}{t_{\text {control }}} \cdot \mathrm{V}$, where $\left[\mathrm{O}_{2}\right]$ is the $\mathrm{O}_{2}$ concentration. The $\mathrm{C}$ respiration rate was derived from the $\mathrm{O}_{2}$ respiration rate, assuming a respiratory quotient $\mathrm{CO}_{2}: \mathrm{O}_{2}=1$; this quotient was measured for $\mathrm{CWCs}$ in situ (Khripounoff et al., 2014). Rates of $\mathrm{NH}_{4}{ }^{+}$excretion and release of POC, PON, DOC, DON (in $\mu \mathrm{mol} \mathrm{C}$ or $\mathrm{N} \mathrm{h}^{-1}$ ) were obtained as

Cor $N$ release $=\frac{[x]_{\text {end, coral }}-[x]_{\text {start, coral }}}{t_{\text {coral }}}-\frac{[x]_{\text {end,control }}-[x]_{\text {start,control }}}{t_{\text {control }}} \cdot V$, where $[\mathrm{x}]$ is the concentration of the respective substance. It should be noted that coral $\mathrm{C}$ and $\mathrm{N}$ release may have been underestimated if coral-produced material was taken up by bacteria during the incubations, i.e. by bacterioplankton passing the $10 \mu \mathrm{m}$-filter and/or by the coral microbiome (Schöttner et al., 2009). Seawater control incubations without corals cannot control for this bacterial uptake. Rates of respiration, ammonium excretion, release of POC, PON, DOC and DON were extrapolated to $24 \mathrm{~h}$ and standardized to coral tissue organic carbon content (tissue-C) as approximation of coral biomass. To facilitate comparability with other studies, we additionally provide $\mathrm{C}$ and $\mathrm{N}$ fluxes standardized to polyp dry mass (determined via buoyant weight) and skeletal dry mass (polyp dry mass - tissue dry mass) in Supplemental Table 1.2.

The daily $\mathrm{C}$ and $\mathrm{N}$ budget of the corals (Fig. 2) was derived as $S f G_{C}=C$ uptake $-C$ respiration $-P O C$ release, and $S f G_{N}=\mathrm{N}$ uptake $-\mathrm{NH}_{4}{ }^{+}$excretion $-\mathrm{PON}$ release, 
397 both in $\mu \mathrm{mol} \mathrm{C} \mathrm{(mmol} \mathrm{tissue-C} \mathrm{d} \mathrm{d}^{-1}$ ). The term 'scope for growth' ( $\mathrm{SfG}$, Warren and Davis 1967) 398 denotes the net $\mathrm{C}$ or $\mathrm{N}$ gains of the corals, which remain from food uptake after subtraction of all $399 \mathrm{C}$ and $\mathrm{N}$ losses. $\mathrm{SfG}>0$ indicates a $\mathrm{C}$ or $\mathrm{N}$ surplus, which can be invested in biomass growth 400 (somatic and/or reproductive), while $\mathrm{SfG}<0$ indicates a $\mathrm{C}$ or $\mathrm{N}$ deficit. It should be noted that 401 DOC and DON release were excluded from the $\mathrm{C}$ and $\mathrm{N}$ budgets, due to the high variability in 402 DOC and DON fluxes (see below). The summed C loss, i.e. C respiration + POC release, was

403

404

405

406

407

408

409

410

411

412

413

414

415

416

417

418

419

420

421

422

423

424

425

426

427

428

429

430

431

432

433

434

435

436 considered as minimum $\mathrm{C}$ demand of the corals, the summed $\mathrm{N}$ loss, i.e. $\mathrm{NH}_{4}{ }^{+}$excretion $+\mathrm{PON}$ release, as their minimum $\mathrm{N}$ demand.

\section{Data analysis}

Graphical and statistical analysis was performed with R (R Core Team, 2017). Values are given as mean \pm standard deviation. Firstly, we tested whether the feeding treatments (within the different feeding scenarios, Fig. 4) had an effect on the $\mathrm{C}$ and $\mathrm{N}$ fluxes, i.e. on the total $\mathrm{C}$ and $\mathrm{N}$ uptake and on rates of $\mathrm{C}$ respiration, $\mathrm{NH}_{4}{ }^{+}$excretion, and release of POC, PON, DOC, DON. For each flux, linear mixed effect (LME) models were fitted, separately for coral batch I and II (Fig. 4), with the function lmer (R package lmerTest, Kuznetsova et al. 2017). The LME models accounted for the repeated measures on the individual corals of the two batches, using coral individuals as random effect and 'feeding treatment + incubation' (i.e. 'zoopl', 'krill.dl', 'krill.d2', 'unfed') as fixed effect (i.e. flux $\sim$ treatment + (1|coral_individual)). In batch I, C and $\mathrm{N}$ fluxes directly (i.e. within the first day) after feeding on zooplankton ('zoopl') were compared with $\mathrm{C}$ and $\mathrm{N}$ fluxes directly after feeding on zooplankton+krill ('krill.dl'); and $\mathrm{C}$ and $\mathrm{N}$ fluxes directly after feeding on zooplankton+krill ('krill.d1') were compared with $\mathrm{C}$ and $\mathrm{N}$ fluxes one day later ('krill.d2'). In batch II, C and N fluxes after feeding on zooplankton ('zoopl') were compared with $\mathrm{C}$ and $\mathrm{N}$ fluxes after four days of food deprivation ('unfed'). Detailed results of the LME models are available as Supplemental Table 1.10. Secondly, $\mathrm{C}$ and $\mathrm{N}$ budgets were visualized by plotting the total $\mathrm{C}$ and $\mathrm{N}$ loss over the total $\mathrm{C}$ and $\mathrm{N}$ uptake (for all $\mathrm{C}$ and $\mathrm{N}$ budgets combined, i.e. 'zoopl', 'krill.d1', 'krill.d2', 'unfed'). The lines 'C loss $=\mathrm{C}$ uptake' and ' $\mathrm{N}$ loss $=\mathrm{N}$ uptake', i.e. ' $\mathrm{SfG}=0$ ', were interpreted as the minimum $\mathrm{C}$ and $\mathrm{N}$ demand of the corals to balance their $\mathrm{C}$ and $\mathrm{N}$ loss, associated with each feeding treatment.

\section{Methodological limitations of this study}

Ex situ experiments, as presented here, allow the measurement of the total $\mathrm{C}$ and $\mathrm{N}$ fluxes of a $\mathrm{CWC}$, i.e. its $\mathrm{C}$ and $\mathrm{N}$ budget. This measurement proves difficult in situ, as it typically requires a closed-off water volume. Nevertheless, ex situ experiments only provide specific simulations of the dynamic fjord environment (González et al., 2010; Jantzen et al., 2013a; Iriarte, 2018). For example, the in situ feeding rate of the corals is unknown. Addition of an 'artificial' experimental amount of zooplankton in the feeding treatments may have led to higher or lower than natural feeding rates. Furthermore, it cannot be excluded that ex situ, the corals were exposed to higher stress than in situ. Stress can enhance the C and N loss of CWCs, e.g. through increased ex situ respiration (Khripounoff et al., 2014) and stress-induced mucus production 
437 (Zetsche et al., 2016). However, we minimized experimental stress, by maintaining the 438 experimental corals in natural fjord water to assure suitable water quality, and by minimum, 439 careful handling. Corals did not show visible signs of stress, such as visibly increased mucus 440 release, retracted tentacles or mortality. Measured DOC and DON fluxes were highly variable 441 (see below) and were therefore excluded from the $\mathrm{C}$ and $\mathrm{N}$ budgets, which likely caused an over442 or underestimate of the coral $\mathrm{C}$ and $\mathrm{N}$ demand. As noted above, bacteria may have taken up 443 coral-produced POC and PON (and DOC, DON) during the incubations, leading to a potential 444 underestimate of these loss terms and the coral $\mathrm{C}$ and $\mathrm{N}$ demand.

445

446 Results

447 Uptake of carbon and nitrogen

448 When fed with zooplankton (treatment 'zooplankton'), D. dianthus captured

$449156 \pm 74$ zooplankton individuals polyp ${ }^{-1} \mathrm{~h}^{-1}$. Given the $2 \mathrm{~h}$-feeding time per day, the total 450 zooplankton capture was $312 \pm 148$ zooplankton individuals $\mathrm{d}^{-1}$, resulting in a $\mathrm{C}$ uptake of $45118.8 \pm 11.5 \mu \mathrm{mol} \mathrm{C}$ (mmol tissue-C) $)^{-1} \mathrm{~d}^{-1}$ (Fig. 5A) and a $\mathrm{N}$ uptake of $4 \pm 2.3 \mu \mathrm{mol} \mathrm{N}$ (mmol 452 tissue-C) $)^{-1} \mathrm{~d}^{-1}$ (Fig. 5B). One euphausiid in addition to zooplankton increased the $\mathrm{C}$ and $\mathrm{N}$ uptake 453 of the corals (of batch I, treatment 'zooplankton+krill') by a factor of four $(67.9 \pm 6.7 \mu \mathrm{mol} \mathrm{C}$ 454 (mmol tissue-C) $)^{-1} \mathrm{~d}^{-1} ; 15.8 \pm 1.8 \mu \mathrm{mol} \mathrm{N}(\text { mmol tissue-C) })^{-1} \mathrm{~d}^{-1}$ ).

455

456

457

458

459

460

461

462

463

464

465

466

467

468

469

470

471

472

473

474

475

476

\section{Respiration and ammonium excretion}

Increasing meal size enhanced the respiration and ammonium excretion rate of $D$. dianthus (Fig. 5C, D), but relatively less compared to the increased $\mathrm{C}$ and $\mathrm{N}$ uptake. Within the first day after feeding on zooplankton, $D$. dianthus respired on average $27.5 \pm 5.8 \mu \mathrm{mol} \mathrm{O}_{2}$ (mmol tissueC) $)^{-1} \mathrm{~d}^{-1}$ and excreted $3.2 \pm 1.3 \mu \mathrm{mol} \mathrm{NH}_{4}{ }^{+}$(mmol tissue-C $)^{-1} \mathrm{~d}^{-1}$. When the corals received krill in addition to zooplankton, they showed an on average $35 \%$ higher respiration rate than when they were fed with zooplankton only (Fig. 5C: 'krill.dl' versus 'zoopl', blue colors). At the same time, their ammonium excretion rate doubled (Fig. 5D). One day after feeding on zooplankton plus krill, the corals showed a lower rate of respiration and ammonium excretion again (Fig. 5C, D: 'krill.d2', corals were not fed between the incubations 'krill.d1' and 'krill.d2'). Four days of food-deprivation reduced the respiration rate of the corals by $29 \%$ and their ammonium excretion rate by $54 \%$, relative to their metabolic activity after feeding on zooplankton (Fig. 5C, D: 'unfed' versus 'zoopl', red colors).

\section{Organic matter release}

Desmophyllum dianthus showed a clear release of POC and PON in all feeding scenarios (Fig. 5E, F). Directly after feeding on zooplankton, corals released $8.2 \pm 6 \mu$ mol POC (mmol tissue-C) $)^{-1} \mathrm{~d}^{-1}$ and $1.7 \pm 0.7 \mu \mathrm{mol}$ PON (mmol tissue-C) ${ }^{-1} \mathrm{~d}^{-1}$ (Fig. 5E, F: 'zooplankton'). Feeding on krill in addition to zooplankton increased the POC release by $67 \%$ and the PON release by 39 \% compared to feeding on zooplankton only (Fig. 5E, F: 'krill.d1' versus 'zoopl', blue colors). One day after feeding on zooplankton plus krill ('krill.d2'), POC and PON release

Peer] reviewing PDF | (2021:07:63798:1:1:NEW 11 Nov 2021) 
477 rates were low $(1.8 \pm 1.0 \mu \mathrm{mol} \text { POC (mmol tissue-C) })^{-1} \mathrm{~d}^{-1}, 0.6 \pm 0.3 \mu$ mol PON (mmol tissue-C)

$478{ }^{1} \mathrm{~d}^{-1}$ ). Four days of food-deprivation reduced POC and PON release by $73 \%$ and $87 \%$ relative to 479 the POC and PON release after feeding on zooplankton (Fig. 5E, F: 'unfed' versus 'zoopl', red 480 colors).

481

482

483

484

485

486

487

488

489

490

491

492

493

494

495

496

497

498

499

500

501

502

503

504

505

506

507

508

509

\section{Discussion}

511 In this study, we report $\mathrm{C}$ and $\mathrm{N}$ budgets of the CWC D. dianthus, an important matrix species of 512 CWC banks in the fjords of the Los Lagos Region, under three different experimental feeding 513 regimes (fed with live fjord zooplankton, fed with zooplankton plus krill, four-day food-

514 deprived). We first discuss the metabolic flexibility (metabolic rate, organic matter release) of

515 the corals in response to varying food availability. Then, we evaluate how the corals could 
516 sustain their $\mathrm{C}$ and $\mathrm{N}$ demand under the low-pH conditions in the fjord and speculate how their $\mathrm{C}$ 517 and $\mathrm{N}$ balance might change in the future.

518

519

520

521

522

523

524

525

526

527

528

529

530

531

532

533

534

535

536

537

538

539

540

541

542

543

544

545

546

547

548

549

550

551

552

553

\section{Metabolic rate}

The CWC $D$. dianthus shows a high metabolic flexibility in response to varying food availability, indicated by increased respiration and ammonium excretion with increasing meal size (from four-day unfed, over zooplankton, to zooplankton plus krill, Fig. 5C, D). The 1.5-fold higher respiration rate within the first day after ingesting a large food ration (zooplankton plus krill, incubation 'krill.d1') as compared to one day later (incubation 'krill.d2; corals not fed between the two incubations) likely reflects the 'specific dynamic action of food' (SDA, Rubner 1902). The SDA describes the increased metabolic rate of animals after feeding, owing to the energetic expenses of food capture and digestion (McCue, 2006; Secor, 2008). The SDA typically increases with meal size, but also varies with meal type (Secor, 2008; present study). Accordingly, krill in addition to zooplankton supplied the corals with four times more $\mathrm{C}$ and $\mathrm{N}$ compared to zooplankton only, but only increased the respiration by a factor of 1.4, probably due to higher energetic costs to capture and process many live, small zooplankters compared to one large, dead euphausiid. Energy costs to process live krill might be higher than for dead krill; however, we assume that the difference is minor, because in feeding trials with live krill, we observed that the corals immobilized their prey within a fraction of a second.

Desmophyllum dianthus responds to short-term food deprivation with a reduction of metabolic rates, likely to conserve energy (Naumann et al. 2011, present study). Corals from Comau Fjord lowered their respiration by $40 \%$ after four days of food deprivation (present study), conspecifics from the Mediterranean deep-sea by $20 \%$ after one week and by $50 \%$ after three weeks of food deprivation (Naumann et al., 2011). This fast, strong reduction of metabolic activity stands in contrast to the closely related CWC Lophelia pertusa, which reduced oxygen consumption only after several months of food deprivation (Larsson, Lundälv \& van Oevelen, 2013; Maier et al., 2019). Overall, in the present study, the respiration rate of $D$. dianthus was around 2.5 times lower $\left(14 \pm 5 \mu \mathrm{mol} \mathrm{O}_{2}(\mathrm{~g} \text { skeletal dry mass })^{-1} \mathrm{~d}^{-1}\right)$ compared to the respiration

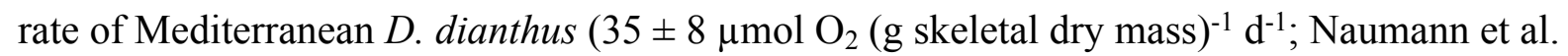
2011), in spite of a comparable feeding history (Artemia salina, krill, $>24 \mathrm{~h}$ after feeding) and temperature $\left(12^{\circ} \mathrm{C}\right)$.

The metabolic flexibility of $D$. dianthus could allow colonization of different habitats, from shallow areas of fjords with a high variability of food, temperature, salinity and $\mathrm{pH}$, to the environmentally more stable, deep CWC habitats (Freiwald et al., 2004). Global warming increases the metabolic rate of CWCs (Dodds et al., 2007; Gori et al., 2016; Dorey et al., 2020), which could cause severe energetical constraints for this and other CWC species.

554

555

\section{Organic matter release}


556 Cold- and warm-water corals release organic matter (POM, DOM), as feces egested from their

557

558

559

560

561

562

563

564

565

566

567

568

569

570

571

572

573

574

575

576

577

578

579

580

581

582

583

584

585

586

587

588

589

590

591

592

593

594

595

gastrovascular cavity (Yonge, 1930) and as coral mucus (Brown \& Bythell, 2005; Naumann et al., 2011). The high POC and PON release by $D$. dianthus within the first day after feeding (Fig. 5E, F) suggests that fecal material accounts for most of its POM release. The CWC species engulfs its prey whole; hence, sloppy feeding sensu Banse (1992), i.e. the loss of organic matter in front of the mouth, can be ruled out. Krill are assimilated at a higher efficiency compared to zooplankton ( $\mathrm{CN}$ assimilation:CN uptake), due to the lower fecal loss in relation to the high $\mathrm{C}$ and $\mathrm{N}$ uptake (Fig. 5).

Four-day-unfed corals continue to release smaller amounts of POM, likely as mucoid material. Coral mucus consists of glycoproteins (Bythell \& Wild, 2011) and serves as protection against sediment smothering, biofouling and as feeding aid (Brown \& Bythell, 2005). Wild et al. (2008) reported that mucus of the CWC $L$. pertusa rapidly dissolved in seawater, hence, the DOC release of this CWC species was $>30$ times higher than its POC release. This high DOC:POC ratio was not confirmed for $D$. dianthus (present study); instead, rates of DOC release/uptake were highly variable (Fig. 5G).

Four-day unfed D. dianthus from Comau Fjord released on average four times more total organic carbon $(7.1 \mu \mathrm{mol} \text { TOC (g skeletal dry mass) })^{-1} \mathrm{~d}^{-1}$; POC plus DOC) than its Mediterranean conspecifics $\left(1.9 \mu \mathrm{mol}\right.$ TOC (g skeletal dry mass) ${ }^{-1} \mathrm{~d}^{-1}$, Naumann et al., 2011). Higher mucus production in the shallow areas of the fjords may serve as protection against higher particle loads (Larsson et al., 2013; Zetsche et al., 2016). In the Comau Fjord, the chlorophyll-a concentration (up to $>50 \mathrm{mg} \mathrm{m}^{-3}$, Garcia-Herrera et al., 2021), and hence turbidity, is orders of magnitude higher than in the deep parts of the oligotrophic Mediterranean $\left(<2 \mathrm{mg} \mathrm{m}^{-3}\right.$; Lo Iacono et al. 2019).

Due to relatively high mucus and fecal loss, the TOC release already contributes $30-60 \%$ to the total C loss of the fjord corals (respiration plus organic matter release). Anthropogenically increased sedimentation, e.g., from the extensive salmon farming in the Chilean fjords (Häussermann et al., 2013; Försterra, Häussermann \& Laudien, 2016), could further increase mucus production and related energy expenditure.

On the steep, partly overhanging fjord walls, $D$. dianthus often co-occurs with other suspension feeders, such as the bivalve Acesta patagonica and the sponge Mycale thielei (Försterra et al., 2005). Like $D$. dianthus, these genera produce large amounts of detrital and/or fecal material (Maier et al., 2020b). The organic matter 'waste' of the suspension feeding community may serve as food for detritivores living underneath the vertical or overhanging walls, ensuring a close material recycling, as suggested for L. pertusa reefs (Rix et al., 2016; Maier et al., 2020b).

\section{Carbon and nitrogen budget}

Peer) reviewing PDF | (2021:07:63798:1:1:NEW 11 Nov 2021) 
596 The CWC D. dianthus in Comau Fjord is characterized by a high $\mathrm{C}$ and $\mathrm{N}$ demand. To account 597 for their costs of respiration, ammonium excretion and POM (mucus) release, unfed corals have 598 to expend $2 \%$ of their tissue- $\mathrm{C}$ and $1.2 \%$ of their tissue- $\mathrm{N}$ per day. With growing meal size, 599 feeding-related costs and losses increase the total $\mathrm{C}$ and $\mathrm{N}$ loss to $4.4 \%$ of the tissue-C and $6006.4 \%$ of the tissue-N. To grow somatic and reproductive tissue, the corals need additional 601 resources. Conspecifics from the Mediterranean show an even higher $\mathrm{C}$ demand, due to their 602 higher respiration rate (Naumann et al., 2011). In comparison, L. pertusa from a Norwegian fjord 603 has a ca. 10-times lower $\mathrm{C}$ demand, due to the lower respiration under the colder $\left(8^{\circ} \mathrm{C}\right)$, less604 acidic conditions, and due to the lower POC release (Maier et al., 2019). Higher temperatures 605 increase the respiration of CWCs and hence their energy demand (Dodds et al., 2007; Gori et al., 606 2016; Dorey et al., 2020). Similarly, a low pH stimulates the production of respiratory-chain 607 enzymes in $D$. dianthus, likewise indicating an increased metabolic activity and energy demand 608 (Carreiro-Silva et al., 2014). Nevertheless, the comparatively high skeletal growth rate of 609 D. dianthus from Comau Fjord, in spite of (relatively) high temperatures and low pH (Jantzen et 610 al., 2013a,b), could indicate that the fjord corals are not food-limited.

611

612 To balance C (or N) losses, a medium-sized D. dianthus polyp in Comau Fjord has to capture 613 almost 700 (or 400) zooplankton individuals $(>100 \mu \mathrm{m}$ ) per day. As a voracious zooplankton 614 predator, $D$. dianthus is capable to exploit high concentrations of zooplankton (Höfer et al., 615 2018), which may occur in swarms at densities of $>1000$ zooplankters $\mathrm{L}^{-1}$ (Ambler, 2002).

616 Zooplankton aggregation was observed at pycnoclines (Tiselius, Nielsen \& Nielsen, 1994), near 617 oceanographic fronts, and in the vicinity of abrupt topography like seamounts or coral reefs 618 (Genin et al., 1994). These aggregations form because zooplankton actively maintains its depth 619 by swimming against vertical currents (Genin et al., 2005). A surprising finding in our 620 experiments was that simulated zooplankton swarms of $>1000$ individuals $\mathrm{L}^{-1}$, leading to the 621 capture of $>300$ zooplankters, were insufficient to balance the daily $\mathrm{C}$ and $\mathrm{N}$ losses of the fjord 622 corals.

623

624 This suggests that krill, or other larger prey, play a crucial role for the nutrition of $D$. dianthus in 625 Comau Fjord. The capture of one euphausiid alone boosts the $\mathrm{C}$ and $\mathrm{N}$ budget of the corals 626 (Fig. 6), firstly due to its ca. 1,000 times higher $\mathrm{C}$ and $\mathrm{N}$ content compared to small zooplankton. 627 Secondly, krill is processed more efficiently compared to zooplankton: On a krill plus

628

629

630

631

632

633

634 zooplankton diet, corals showed a higher assimilation efficiency (lower feeding-related POC and PON release in relation to $\mathrm{C}$ and $\mathrm{N}$ uptake, see above) and growth efficiency (lower metabolic costs, i.e. respiration, ammonium excretion in relation to $\mathrm{C}$ and $\mathrm{N}$ uptake, see above). We observed dense krill swarms directly next to the corals during dives by remotely-operated vehicle between 160 and $200 \mathrm{~m}$ depth (Fig. 7) and during SCUBA dives at $20 \mathrm{~m}$ depth. Likewise, the recurrence of blue whales in Comau Fjord (Försterra \& Häussermann, 2012) indicates krill aggregations, which are known to attract the large mammals in the region (Buchan \& Quiñones, 
635 2016). In feeding experiments, $D$. dianthus captured live krill at a similar rate $\left(18 \% \mathrm{~h}^{-1}\right)$ as small

636

637

638

639

640

641

642

643

644

645

646

647

648

649

650

651

652

653

654

655

656

657

658

659

660

661

662

663

664

665

666

667

668

669

670

671

\section{2}

673

674

zooplankton (Höfer et al., 2018); in situ, krill capture remains to be quantified.

A maximized energy intake is crucial considering the pronounced seasonality in North Patagonia (Pickard, 1971). The $\mathrm{C}$ and $\mathrm{N}$ budget of $D$. dianthus was assessed in austral summer, when high abundances of zooplankton and krill follow the spring phytoplankton bloom (Iriarte et al., 2007; González et al., 2010) and create feast conditions. The CWCs might invest the excess resources in tissue reserves such as lipids (Maier et al., 2019) to overcome the less-productive winter (Iriarte et al., 2007; González et al., 2010). In early spring (September), however, Patagonian D. dianthus also starts to produce gametes, which is an energy-costly process (Feehan, Waller \& Häussermann, 2019). Reduced skeletal growth in summer could therefore indicate an energetic trade-off between investment in reproductive tissue and growth (Hassenrück et al., 2013), as suggested for L. pertusa from a Norwegian fjord (Maier et al., 2020a). In winter, when zooplankton and krill abundance is reduced, the corals may benefit from their metabolic flexibility. The fast downregulation of metabolic rate and POM release constrains $\mathrm{C}$ and $\mathrm{N}$ losses. Further, after prolonged (3-week) zooplankton exclusion, D. dianthus was observed to take up alternative resources, such as DOM and/or non-zooplankton POM (Naumann et al., 2011). A potential diet shift to more degraded material in winter was also described for the CWC L. pertusa (Maier et al., 2020a). Metabolic and dietary flexibility enable the fjord corals to survive without particulate food for several months, as we recently observed.

By the end of the century, most CWC ecosystems are predicted to face ocean acidification with anthropogenically lowered $\mathrm{pH}$ levels comparable to those occurring naturally in Comau Fjord at present (Guinotte et al., 2006; Jantzen et al., 2013; Fillinger \& Richter, 2013). Our study indicates that a high energy supply is crucial for $D$. dianthus to grow in its low-pH fjord habitat. Similarly, CWCs showed a higher (growth) resilience to experimentally acidified conditions when their energy supply was high (Georgian et al., 2016; Martínez-Dios et al., 2020). On top of food quantity (e.g. the amount of $\mathrm{C}$ and $\mathrm{N}$ ), a high food quality increases assimilation and growth efficiency of CWCs (present study) and hence their reserves to actively counteract adverse conditions (Carreiro-Silva et al., 2014). Nevertheless, there are currently no indications that zooplankton and krill supply to CWC may increase to offset a changing $\mathrm{C}$ and $\mathrm{N}$ budget in the future. In contrast, on a global scale, climate change is decreasing the productivity at the ocean surface, the efficiency of the biological pump and accordingly the food supply to deeper, benthic ecosystems (Bopp et al., 2001, 2005; Gregg et al., 2003). A decreased energy supply, in combination with an increased energy demand, could have a large, negative impact on the fitness of the local population of $D$. dianthus we studied in particular, and global CWCs in general.

\section{Conclusions}

The CWC D. dianthus from the fjords of the Los Lagos Region in North Patagonia requires a substantial supply of pelagic food to balance its daily $\mathrm{C}$ and $\mathrm{N}$ loss through respiration, 
675 ammonium excretion and POM release. Experimental feeding on zooplankton alone was not 676 enough to balance their $\mathrm{C}$ and $\mathrm{N}$ loss, despite the high zooplankton food concentration. For a 677 balanced C (or N) budget, the solitary coral needs to capture a minimum of 700 (or 400) 678 zooplankton individuals per polyp and day, or one larger prey item such as one euphausiid. 679 Under experimental food deprivation, the corals swiftly reduced all $\mathrm{C}$ and $\mathrm{N}$ loss terms, likely to 680 conserve energy. We argue that the exploitation of zooplankton swarms and/or the consumption 681 of krill, combined with a high metabolic flexibility, are important in sustaining the energetic 682 requirements of $D$. dianthus in Comau Fjord under naturally low $\mathrm{pH}$. The bulk of the population, 683 however, thrives in deeper waters under even lower $\mathrm{pH}$, near or below aragonite saturation 684 (Fillinger \& Richter, 2013; Jantzen et al., 2013a), which may further increase their energy 685

686 demand (Gattuso, Allemand \& Frankignoulle, 1999; Cohen \& Holcomb, 2009); this may be

687

688

689

690

691

692

693

694

695

696

697

698

699 evaluated in the future by carrying out similar measurements as presented here in situ, along the $\mathrm{pH}$ depth gradient. Climate change, ocean acidification and the intense salmon aquaculture in the Patagonian fjord region likely impact the energetic balance of $D$. dianthus. The species appears particularly sensitive to a combination of stressors, such as high temperatures and acidification (Gori et al., 2016) or hypoxia and elevated levels of sulfide/methane (Försterra et al., 2014). A disrupted energy balance may have severe consequences for the growth, reproduction and hence the distribution of this and other habitat-forming cold-water coral species.

\section{Acknowledgements}

We thank the team of the Fundación Huinay, especially Reinhard Fitzek, Dan Genter, Soledad Gonzáles, Fernando Hernández, Mauri Melipillán, and Emma Plotnek and for logistic support, and Lisa Reichel and Jens Müller for Scientific Diving. Gerd Liebezeit from the ICBMTerramare Wilhelmshaven provided nutrient analysis. Matthias Friebe kindly assisted in DOC analysis. This is publication no. 172 of Huinay Scientific Field Station.

700

701

702

703

704

705

706

707

708

709

710

711

712

713

\section{References}

Ambler JW. 2002. Zooplankton swarms: characteristics, proximal cues and proposed advantages. Hydrobiologia 480:155-164. DOI: 10.1023/A:1021201605329.

Anagnostou E, Huang KF, You CF, Sikes EL, Sherrell RM. 2012. Evaluation of boron isotope ratio as a $\mathrm{pH}$ proxy in the deep sea coral Desmophyllum dianthus: Evidence of physiological $\mathrm{pH}$ adjustment. Earth and Planetary Science Letters 349:251-260. DOI: 10.1016/j.eps1.2012.07.006. Banse K. 1992. Grazing, temporal changes of phytoplankton concentrations, and the microbial loop in the open sea. In: Falkowski PG, Woodhead AD, Vivirito K eds. Primary Productivity and Biogeochemical Cycles in the Sea. Environmental Science Research. Boston, MA: Springer US, 409-440. DOI: 10.1007/978-1-4899-0762-2_22.

Bopp L, Aumont O, Cadule P, Alvain S, Gehlen M. 2005. Response of diatoms distribution to global warming and potential implications: A global model study. Geophysical Research Letters 32. DOI: 10.1029/2005GL023653. 
714 Bopp L, Monfray P, Aumont O, Dufresne J-L, Le Treut H, Madec G, Terray L, Orr JC. 2001.

715 Potential impact of climate change on marine export production. Global Biogeochemical Cycles

716 15:81-89. DOI: 10.1029/1999GB001256.

717 Brown BE, Bythell JC. 2005. Perspectives on mucus secretion in reef corals. Marine Ecology

718 Progress Series 296:291-309. DOI: 10.3354/meps296291.

719 Buchan SJ, Quiñones RA. 2016. First insights into the oceanographic characteristics of a blue 720 whale feeding ground in northern Patagonia, Chile. Marine Ecology Progress Series 554:183-

721 199. DOI: $10.3354 /$ meps 11762.

722 Büscher J, Form AU, Riebesell U. 2017. Interactive effects of ocean acidification and warming

723 on growth, fitness and survival of the cold-water coral Lophelia pertusa under different food

724 availabilities. Frontiers in Marine Science 4. DOI: 10.3389/fmars.2017.00101.

725 Buschmann AH, Cabello F, Young K, Carvajal J, Varela DA, Henríquez L. 2009. Salmon

726 aquaculture and coastal ecosystem health in Chile: Analysis of regulations, environmental

727 impacts and bioremediation systems. Ocean \& Coastal Management 52:243-249. DOI:

728 10.1016/j.ocecoaman.2009.03.002.

729 Bythell JC, Wild C. 2011. Biology and ecology of coral mucus release. Journal of Experimental

730 Marine Biology and Ecology 408:88-93. DOI: 10.1016/j.jembe.2011.07.028.

731 Cairns SD, Häussermann V, Försterra G. 2005. A review of the Scleractinia (Cnidaria:

732 Anthozoa) of Chile, with the description of two new species. Zootaxa 1018:15-46. DOI:

733 10.11646/zootaxa.1018.1.2.

734 Caldeira K, Wickett ME. 2003. Anthropogenic carbon and ocean pH. Nature 425:365-365. DOI:

735 10.1038/425365a.

736 Carreiro-Silva M, Cerqueira T, Godinho a., Caetano M, Santos RS, Bettencourt R. 2014.

737 Molecular mechanisms underlying the physiological responses of the cold-water coral

738 Desmophyllum dianthus to ocean acidification. Coral Reefs 33:465-476. DOI: 10.1007/s00338-

739 014-1129-2.

740 Chen CTA, Feely RA, Gendron JF. 1988. Lysocline, calcium carbonate compensation depth, and

741 calcareous sediments in the North Pacific Ocean. Pacific Science 42:237-252.

742 Cohen AL, Holcomb M. 2009. Why corals care about ocean acidification: uncovering the

743 mechanism. Oceanography 22:118-127. DOI: 10.5670/oceanog.2009.102.

744 Davies PS. 1989. Short-term growth measurements of corals using an accurate buoyant weighing

745 technique. Marine Biology 101:389-395. DOI: 10.1007/BF00428135.

746 Dodds LA, Roberts JM, Taylor AC, Marubini F. 2007. Metabolic tolerance of the cold-water

747 coral Lophelia pertusa (Scleractinia) to temperature and dissolved oxygen change. Journal of

748 Experimental Marine Biology and Ecology 349:205-214. DOI: 10.1016/j.jembe.2007.05.013.

749 Dorey N, Gjelsvik Ø, Kutti T, Büscher JV. 2020. Broad thermal tolerance in the cold-water coral

750 Lophelia pertusa from Arctic and boreal reefs. Frontiers in Physiology 10. DOI:

751 10.3389/fphys.2019.01636. 
752 Feehan KA, Waller RG, Häussermann V. 2019. Highly seasonal reproduction in deep-water

753 emergent Desmophyllum dianthus (Scleractinia: Caryophylliidae) from the Northern Patagonian

754 Fjords. Marine Biology 166:52. DOI: 10.1007/s00227-019-3495-3.

755 Fillinger L, Richter C. 2013. Vertical and horizontal distribution of Desmophyllum dianthus in

756 Comau Fjord, Chile: a cold-water coral thriving at low pH. PeerJ 1. DOI: 10.7717/peerj.194.

757 Findlay HS, Wood HL, Kendall MA, Spicer JI, Twitchett RJ, Widdicombe S. 2011. Comparing

758 the impact of high $\mathrm{CO}_{2}$ on calcium carbonate structures in different marine organisms. Marine

759 Biology Research 7:565-575. DOI: 10.1080/17451000.2010.547200.

760 Försterra G, Beuck L, Häussermann V, Freiwald A. 2005. Shallow-water Desmophyllum

761 dianthus (Scleractinia) from Chile: characteristics of the biocoenoses, the bioeroding community,

762 heterotrophic interactions and (paleo)-bathymetric implications. In: Freiwald A, Roberts JM eds.

763 Cold-Water Corals and Ecosystems. Erlangen Earth Conference Series. Berlin, Heidelberg:

764 Springer, 937-977. DOI: 10.1007/3-540-27673-4_48.

765 Försterra G, Häussermann V. 2003. First report on large scleractinian (Cnidaria: Anthozoa)

766 accumulations in cold-temperate shallow water of south Chilean fjords. Zoologische

767 Verhandelingen 345:117-128.

768 Försterra G, Häussermann V. 2012. Report on blue whales sightings (Balaenoptera musculus

769 Linnaeus, 1758) in a narrow fjord during autumn-winter in southern Chile. Spixiana 35:237-245.

770 Försterra G, Häussermann V, Laudien J, Jantzen C, Sellanes J, Muñoz P. 2014. Mass die off of

771 the cold-water coral Desmophyllum dianthus in the Chilean Patagonian fjord region. Bulletin of

772 Marine Science 90:1-6. DOI: 10.5343/bms.2013.1064.

773 Försterra G, Häussermann V, Laudien J. 2016. Animal forests in the Chilean fjords: discoveries,

774 perspectives and threats in shallow and deep waters. Available at

775 https://epic.awi.de/id/eprint/45591/(accessed May 21, 2021).

776 Freiwald A, Fosså JH, Grehan A, Koslow T, Roberts JM. 2004. Cold-water coral reefs.

777 Cambridge, UK.

778 Garcia-Herrera N, Cornils A, Laudien J, Niehoff B, Höfer J, González HE, Richter C (2021).

779 Physical oceanography in Spring 2017 of Comau Fjord, Chilean Patagonia. PANGAEA,

780 https://doi.pangaea.de/10.1594/PANGAEA.937445 (dataset in review).

781 Gattuso J-P, Allemand D, Frankignoulle M. 1999. Photosynthesis and calcification at cellular,

782 organismal and community levels in coral reefs: a review on interactions and control by

783 carbonate chemistry. American Zoologist 39:160-183. DOI: 10.1093/icb/39.1.160.

784 Genin A, Greene C, Haury L, Wiebe P, Gal G, Kaartvedt S, Meir E, Fey C, Dawson J. 1994.

785 Zooplankton patch dynamics: daily gap formation over abrupt topography. Deep Sea Research

786 Part I: Oceanographic Research Papers 41:941-951. DOI: 10.1016/0967-0637(94)90085-X.

787 Genin A, Jaffe JS, Reef R, Richter C, Franks PJS. 2005. Swimming against the flow: a

788 mechanism of zooplankton aggregation. Science 308:860-862. DOI: 10.1126/science. 1107834.

789 Georgian SE, Shedd W, Cordes EE. 2014. High-resolution ecological niche modelling of the

790 cold-water coral Lophelia pertusa in the Gulf of Mexico. Marine Ecology Progress Series

791 506:145-161. DOI: 10.3354/meps10816. 
792 González HE, Calderón MJ, Castro L, Clement A, Cuevas LA, Daneri G, Iriarte JL, Lizárraga L,

793 Martínez R, Menschel E, Silva N, Carrasco C, Valenzuela C, Vargas CA, Molinet C. 2010.

794 Primary production and plankton dynamics in the Reloncaví Fjord and the Interior Sea of Chiloé,

795 Northern Patagonia, Chile. Marine Ecology Progress Series 402:13-30. DOI:

796 10.3354/meps08360.

797 Gori A, Ferrier-Pagès C, Hennige SJ, Murray F, Rottier C, Wicks LC, Roberts JM. 2016.

798 Physiological response of the cold-water coral Desmophyllum dianthus to thermal stress and

799 ocean acidification. PeerJ 4:e1606. DOI: 10.7717/peerj.1606.

800 Grasshoff K, Ehrhardt M, Kremling K eds. 1983. Methods of seawater analysis. Weinheim,

801 Germany: Verlag Chemie GmbH.

802 Gregg WW, Conkright ME, Ginoux P, O’Reilly JE, Casey NW. 2003. Ocean primary production

803 and climate: global decadal changes. Geophysical Research Letters 30:1809. DOI:

804 10.1029/2003GL016889.

805 Guinotte JM, Orr J, Cairns S, Freiwald A, Morgan L, George R. 2006. Will human-induced

806 changes in seawater chemistry alter the distribution of deep-sea scleractinian corals? Frontiers in

807 Ecology and the Environment 4:141-146. DOI: 10.1890/1540-

808 9295(2006)004[0141:WHCISC]2.0.CO;2.

809 Hassenrück C, Jantzen C, Försterra G, Häussermann V, Willenz P. 2013. Rates of apical septal

810 extension of Desmophyllum dianthus: Effect of association with endolithic photo-autotrophs.

811 Marine Biology 160:2919-2927. DOI: 10.1007/s00227-013-2281-x.

812 Häussermann V, Försterra G, Melzer RR, Meyer R. 2013. Gradual changes of benthic

813 biodiversity in Comau Fjord, Chilean Patagonia - lateral observations over a decade of

814 taxonomic research. Spixiana 36.2:161-171.

815 Hedges JI, Stern JH. 1984. Carbon and nitrogen determinations of carbonate-containing solids.

816 Limnology and Oceanography 29:657-663. DOI: 10.4319/10.1984.29.3.0657.

817 Hennige SJ, Wicks LC, Kamenos NA, Perna G, Findlay HS, Roberts JM. 2015. Hidden impacts

818 of ocean acidification to live and dead coral framework. Proceedings of the Royal Society B:

819 Biological Sciences 282:1-10. DOI: 10.1098/rspb.2015.0990.

820 Henry L-A, Roberts JM. 2016. Global biodiversity in cold-water coral reef ecosystems. In: Rossi

821 S, Bramanti L, Gori A, Orejas Saco del Valle C eds. Marine Animal Forests: The Ecology of

822 Benthic Biodiversity Hotspots. Cham: Springer International Publishing, 1-21. DOI:

823 10.1007/978-3-319-17001-5_6-1.

824 Hirche H-J, Laudien J, Buchholz F. 2016. Near-bottom zooplankton aggregations in

825 Kongsfjorden: implications for pelago-benthic coupling. Polar Biology 39:1897-1912. DOI:

826 10.1007/s00300-015-1799-4.

827 Höfer J, González HE, Laudien J, Schmidt GM, Häussermann V, Richter C. 2018. All you can

828 eat: the functional response of the cold-water coral Desmophyllum dianthus feeding on krill and 829 copepods. PeerJ 6:e5872. DOI: 10.7717/peerj.5872.

830 Iriarte JL. 2018. Natural and human influences on marine processes in Patagonian Subantarctic

831 coastal waters. Frontiers in Marine Science 5. DOI: 10.3389/fmars.2018.00360. 
832 Iriarte JL, González HE, Liu KK, Rivas C, Valenzuela C. 2007. Spatial and temporal variability 833 of chlorophyll and primary productivity in surface waters of southern Chile (41.5-43 $\left.{ }^{\circ} \mathrm{S}\right)$.

834 Estuarine, Coastal and Shelf Science 74:471-480. DOI: 10.1016/j.ecss.2007.05.015.

835 Jantzen C, Häussermann V, Försterra G, Laudien J, Ardelan M, Maier S, Richter C. 2013a.

836 Occurrence of a cold-water coral along natural $\mathrm{pH}$ gradients (Patagonia, Chile). Marine Biology 837 160:2597-2607. DOI: 10.1007/s00227-013-2254-0.

838 Jantzen C, Laudien J, Sokol S, Försterra G, Häussermann V, Kupprat F, Richter C. 2013b. In situ 839 short-term growth rates of a cold-water coral. Marine and Freshwater Research 64:631-641. 840 DOI: $10.1071 / \mathrm{MF} 12200$.

841 Jantzen C, Schmidt GM, Wild C, Roder C, Khokiattiwong S, Richter C. 2013c. Benthic reef 842 primary production in response to large amplitude internal waves at the Similan Islands 843 (Andaman Sea, Thailand). PLoS ONE 8:e81834. DOI: 10.1371/journal.pone.0081834.

844 Jiang L-Q, Feely RA, Carter BR, Greeley DJ, Gledhill DK, Arzayus KM. 2015. Climatological

845 distribution of aragonite saturation state in the global oceans. Global Biogeochemical Cycles 846 29:1656-1673. DOI: 10.1002/2015GB005198.

847 Jones OA, Endean R (eds.). 1973. Biology and Geology of Coral Reefs V2: Biology 1. New 848 York: Academic Press, Inc.

849 Jones CG, Lawton JH, Shachak M. 1994. Organisms as ecosystem engineers. In: Samson FB, 850 Knopf FL eds. Ecosystem Management: Selected Readings. New York, NY: Springer, 130-147. 851 DOI: 10.1007/978-1-4612-4018-1_14.

852 Khripounoff A, Caprais J-C, Le Bruchec J, Rodier P, Noel P, Cathalot C. 2014. Deep cold-water 853 coral ecosystems in the Brittany submarine canyons (Northeast Atlantic): Hydrodynamics, 854 particle supply, respiration, and carbon cycling. Limnology and Oceanography 59:87-98. DOI: 855 10.4319/1o.2014.59.01.0087.

856 Kuznetsova A, Brockhoff P, Christensen R. 2017. lmerTest Package: Tests in Linear Mixed 857 Effects Models. Journal of Statistical Software 82:1-26. DOI:

858 https://doi.org/10.18637/jss.v082.i13.

859 Larsson AI, Lundälv T, van Oevelen D. 2013. Skeletal growth, respiration rate and fatty acid 860 composition in the cold-water coral Lophelia pertusa under varying food conditions. Marine 861 Ecology Progress Series 483:169-184. DOI: 10.3354/meps10284.

862 Larsson AI, van Oevelen D, Purser A, Thomsen L. 2013. Tolerance to long-term exposure of 863 suspended benthic sediments and drill cuttings in the cold-water coral Lophelia pertusa. Marine 864 Pollution Bulletin 70:176-188. DOI: 10.1016/j.marpolbul.2013.02.033.

865 Larsson AI, Purser A. 2011. Sedimentation on the cold-water coral Lophelia pertusa: Cleaning 866 efficiency from natural sediments and drill cuttings. Marine Pollution Bulletin 62:1159-1168. 867 DOI: 10.1016/j.marpolbul.2011.03.041.

868 Lo Iacono C, Savini A, Huvenne VAI, Gràcia E. 2019. 15 Habitat Mapping of Cold-Water 869 Corals in the Mediterranean Sea. In: Orejas C, Jiménez C eds. Mediterranean cold-water corals: 870 past, present and future: understanding the deep-sea realms of coral. Coral Reefs of the World. 871 Cham: Springer International Publishing, 157-171. DOI: 10.1007/978-3-319-91608-8_15. 
872 Maier SR, Bannister RJ, van Oevelen D, Kutti T. 2020a. Seasonal controls on the diet, metabolic 873 activity, tissue reserves and growth of the cold-water coral Lophelia pertusa. Coral Reefs 874 39:173-187. DOI: 10.1007/s00338-019-01886-6.

875 Maier SR, Kutti T, Bannister RJ, Breugel P van, Rijswijk P van, van Oevelen D. 2019. Survival 876 under conditions of variable food availability: resource utilization and storage in the cold-water 877 coral Lophelia pertusa. Limnology and Oceanography 64:1651-1671. DOI: 10.1002/lno.11142. 878 Maier SR, Kutti T, Bannister RJ, Fang JK-H, van Breugel P, van Rijswijk P, van Oevelen D. 879 2020b. Recycling pathways in cold-water coral reefs: Use of dissolved organic matter and 880 bacteria by key suspension feeding taxa. Scientific Reports 10:9942. DOI: 10.1038/s41598-020881 66463-2.

882 Martínez-Dios A, Pelejero C, López-Sanz À, Sherrell RM, Ko S, Häussermann V, Försterra G, 883 Calvo E. 2020. Effects of low $\mathrm{pH}$ and feeding on calcification rates of the cold-water coral 884 Desmophyllum dianthus. PeerJ 8:e8236. DOI: 10.7717/peerj.8236.

885 Mayr CC, Försterra G, Häussermann V, Wunderlich A, Grau J, Zieringer M, Altenbach AV. 886 2011. Stable isotope variability in a Chilean fjord food web: implications for N- and C-cycles.

887 Marine Ecology Progress Series 428:89-104. DOI: 10.3354/meps09015.

888 Mayr C, Rebolledo L, Schulte K, Schuster A, Zolitschka B, Försterra G, Häussermann V. 2014. 889 Responses of nitrogen and carbon deposition rates in Comau Fjord (42 ${ }^{\circ} \mathrm{S}$, southern Chile) to 890 natural and anthropogenic impacts during the last century. Continental Shelf Research 78:1-10. 891 DOI: 10.1016/j.csr.2014.02.004.

892 McCue MD. 2006. Specific dynamic action: a century of investigation. Comparative

893 Biochemistry and Physiology Part A: Molecular \& Integrative Physiology 144:381-394. DOI:

894 10.1016/j.cbpa.2006.03.011.

895 McCulloch M, Falter J, Trotter J, Montagna P. 2012. Coral resilience to ocean acidification and 896 global warming through $\mathrm{pH}$ up-regulation. Nature Climate Change 2:623-627. DOI:

$89710.1038 /$ nclimate1473.

898 Melzner F, Gutowska M a., Langenbuch M, Dupont S, Lucassen M, Thorndyke MC, Bleich M, 899 Pörtner H-O. 2009. Physiological basis for high $\mathrm{CO}_{2}$ tolerance in marine ectothermic animals:

900 pre-adaptation through lifestyle and ontogeny? Biogeosciences 6:4693-4738. DOI: 10.5194/bg901 6-2313-2009.

902 Møller LF, Riisgård HU. 2007. Feeding, bioenergetics and growth in the common jellyfish 903 Aurelia aurita and two hydromedusae, Sarsia tubulosa and Aequorea vitrina. Marine Ecology 904 Progress Series 346:167-177. DOI: 10.3354/meps06959.

905 Montero P, Daneri G, González HE, Iriarte JL, Tapia FJ, Lizárraga L, Sanchez N, Pizarro O. 906 2011. Seasonal variability of primary production in a fjord ecosystem of the Chilean Patagonia: 907 Implications for the transfer of carbon within pelagic food webs. Continental Shelf Research 908 31:202-215. DOI: 10.1016/j.csr.2010.09.003.

909 Naumann MS, Orejas C, Wild C, Ferrier-Pages C. 2011. First evidence for zooplankton feeding 910 sustaining key physiological processes in a scleractinian cold-water coral. Journal of

911 Experimental Biology 214:3570-3576. DOI: 10.1242/jeb.061390. 
912 Pickard GL. 1971. Some physical oceanographic features of inlets of Chile. Journal of the

913 Fisheries Board of Canada 28:1077-1106. DOI: 10.1139/f71-163.

914 R Core Team. 2017. R: A language and environment for statistical computing. $R$ Foundation for

915 Statistical Computing, Vienna, Austria. URL https://www.R-project.org/.

916 Rix L, Naumann MS, de Goeij JM, Mueller CE, Struck U, Middleburg JJ, van Duyl FC, Al-

917 Horani FA, Wild C, van Oevelen D. 2016. Coral mucus fuels the sponge loop in warm- and cold-

918 water coral reef ecosystems. Scientific Reports 6:1-11. DOI: 10.1038/srep18715.

919 Roberts JM, Wheeler AJ, Freiwald A. 2006. Reefs of the deep: the biology and geology of cold920 water coral ecosystems. Science 312:543-547. DOI: 10.1126/science.1119861.

921 Rossi S, Bramanti L, Gori A, Orejas C. 2017. Marine animal forests: the ecology of benthic

922 biodiversity hotspots. Cham, Switzerland: Springer International Publishing.

923 Rubner M. 1902. Die Gesetze des Energieverbrauchs bei der Ernaehrung. Franz Deuticke,

924 Lepizig.

925 Sánchez N, Gonzales HE, Iriarte JL. 2011. Trophic interactions of pelagic crustaceans in Comau 926 Fjord (Chile): their role in the food web structure. Journal of Plankton Research 33:1212-1229. 927 DOI: 10.1093/plankt/fbr022.

928 Schöttner S, Hoffmann F, Wild C, Rapp HT, Boetius A, Ramette A. 2009. Inter- and intra929 habitat bacterial diversity associated with cold-water corals. The ISME Journal 3:756-759. DOI: $930 \quad 10.1038 /$ ismej.2009.15.

931 Sebens KP, Vandersall KS, Savina LA, Graham KR. 1996. Zooplankton capture by two 932 scleractinian corals, Madracis mirabilis and Montastrea cavernosa, in a field enclosure. Marine 933 Biology 127:303-317. DOI: 10.1007/BF00942116.

934 Secor SM. 2008. Specific dynamic action: a review of the postprandial metabolic response. 935 Journal of Comparative Physiology B: Biochemical, Systemic, and Environmental Physiology 936 179:1-56. DOI: 10.1007/s00360-008-0283-7.

937 Soetaert K, van Oevelen D. 2009. Modeling food web interactions in benthic deep-sea 938 ecosystems. A practical guide. Oceanography 22:128-143. DOI: 10.5670/oceanog.2009.13. 939 Sokol S. 2012. The influence of heterotrophy and flow on calcification of the cold-water coral 940 Desmophyllum dianthus. Master Thesis. Christian-Albrechts-University of Kiel, Germany. 941 Sugimura Y, Suzuki Y. 1988. A high-temperature catalytic oxidation method for the 942 determination of non-volatile dissolved organic carbon in seawater by direct injection of a liquid 943 sample. Marine Chemistry 24:105-131. DOI: 10.1016/0304-4203(88)90043-6.

944 Tiselius P, Nielsen G, Nielsen TG. 1994. Microscale patchiness of plankton within a sharp 945 pycnocline. Journal of Plankton Research 16:543-554. DOI: 10.1093/plankt/16.5.543.

946 Trotter J, Montagna P, Mcculloch M, Silenzi S, Reynaud S, Mortimer G, Martin S, Ferrier-Pagès 947 C, Gattuso J-P, Rodolfo-Metalpa R. 2011. Quantifying the $\mathrm{pH}$ 'vital effect' in the temperate 948 zooxanthellate coral Cladocora caespitosa: validation of the boron seawater $\mathrm{pH}$ proxy. Earth 949 and Planetary Science Letters 303:163-173. DOI: 10.1016/j.eps1.2011.01.030. 
950 Turley CM, Roberts JM, Guinotte JM. 2007. Corals in deep-water: will the unseen hand of ocean 951 acidification destroy cold-water ecosystems? Coral Reefs 26:445-448. DOI: 10.1007/s00338952 007-0247-5.

953 Vidal-Dupiol J, Zoccola D, Tambutté E, Grunau C, Cosseau C, Smith KM, Freitag M, Dheilly 954 NM, Allemand D, Tambutte S. 2013. Genes related to ion-transport and energy production are 955 upregulated in response to $\mathrm{CO}_{2}$-driven $\mathrm{pH}$ decrease in corals: new insights from transcriptome 956 analysis. PLoS ONE 8:e58652. DOI: 10.1371/journal.pone.0058652.

957 Warren CE, Davis GE. 1967. Laboratory studies on the feeding, bioenergetics, and growth of 958 fish. In: Gerking SD ed. The Biological Basis of Freshwater Fish Production. London:

959 Blackwell, 175-214.

960 Wild C, Mayr C, Wehrmann L, Schöttner S, Naumann M, Hoffmann F, Rapp HT. 2008. Organic

961 matter release by cold water corals and its implication for fauna-microbe interaction. Marine

962 Ecology Progress Series 372:67-75. DOI: 10.3354/meps07724.

963 Yonge CM. 1930. Studies on the physiology of corals: 1. Feeding mechanisms and food. Great

964 Barrier Reef Expedition 1928-29 Scientific Reports 1:1-57.

965 Zetsche EM, Baussant T, Meysman FJR, van Oevelen D. 2016. Direct visualization of mucus

966 production by the cold-water coral Lophelia pertusa with digital holographic microscopy. PLoS

967 ONE 11:e014676.

968 Zheng M-D, Cao L. 2014. Simulation of global ocean acidification and chemical habitats of 969 shallow- and cold-water coral reefs. Advances in Climate Change Research 5:189-196. DOI:

970 10.1016/j.accre.2015.05.002. 


\section{Table $\mathbf{1}$ (on next page)}

Minimum $\mathrm{C}$ and $\mathrm{N}$ demand of Desmophyllum dianthus, under different feeding treatments.

Feeding treatments were 'zoopl': corals fed with zooplankton; 'krill.d1': corals fed with zooplankton+krill, within the first day after feeding; 'krill.d2': corals fed with zooplankton+krill, $24 \mathrm{~h}$ after feeding; 'unfed': corals 4-day unfed. The minimum $\mathrm{C}$ demand of the corals was derived from their $\mathrm{C}$ loss in terms of respiration and release of particulate organic carbon (POC); their minimum $\mathrm{N}$ demand was calculated from their $\mathrm{N}$ loss in terms of ammonium excretion and release of particulate organic nitrogen (PON). Release of dissolved organic carbon and nitrogen (DOC, DON) are excluded here. $\mathrm{C}$ and $\mathrm{N}$ demand are given in different units, as indicated. 


\begin{tabular}{|c|c|c|c|c|c|c|}
\hline \multirow{2}{*}{$\begin{array}{c}\text { Fee- } \\
\text { ding } \\
\text { treat- } \\
\text { ment }\end{array}$} & \multicolumn{3}{|c|}{$\begin{array}{c}\text { Min. C demand } \\
(=\mathrm{C} \text { loss; excluding DOC release })\end{array}$} & \multicolumn{3}{c|}{$\begin{array}{c}\text { Min. N demand } \\
(=\mathrm{N} \text { loss; excluding DON release })\end{array}$} \\
\cline { 2 - 7 } & $\begin{array}{c}(\mu \mathrm{mol} \mathrm{C} \\
\left.\text { polyp }{ }^{-1} \mathrm{~d}^{-1}\right)\end{array}$ & $\begin{array}{c}(\mu \mathrm{mol} \mathrm{C} \\
\left.\mathrm{mmol}^{-1} \mathrm{C}^{-1}\right)\end{array}$ & $\begin{array}{c}(\% \text { of } \\
\text { tissue-C })\end{array}$ & $\begin{array}{c}(\mu \mathrm{mol} \mathrm{N} \\
\left.\mathrm{C}^{-1} \mathrm{~d}^{-1} \mathrm{~d}^{-1}\right)\end{array}$ & $\begin{array}{c}(\mu \mathrm{mol} \mathrm{N} \\
\text { mmol-tissue- } \\
\left.\mathrm{C}^{-1} \mathrm{~d}^{-1}\right)\end{array}$ & $\begin{array}{c}\% \text { of } \\
\text { tissue-N })\end{array}$ \\
\hline zoopl & $89.3 \pm 31.4$ & $35.6 \pm 10.3$ & $3.6 \pm 1.0$ & $11.9 \pm 3.4$ & $4.9 \pm 1.5$ & $3.3 \pm 0.9$ \\
\hline krill.d1 & $108.4 \pm 27.2$ & $44.0 \pm 5.0$ & $4.4 \pm 0.5$ & $23.8 \pm 8.9$ & $9.4 \pm 1.0$ & $6.4 \pm 1.0$ \\
\hline krill.d2 & $61.6 \pm 16.8$ & $24.9 \pm 2.9$ & $2.5 \pm 0.3$ & $13.5 \pm 7.5$ & $5.2 \pm 2.3$ & $3.6 \pm 1.9$ \\
\hline unfed & $52.7 \pm 23.6$ & $20.0 \pm 4.9$ & $2.0 \pm 0.5$ & $3.6 \pm 4.1$ & $1.7 \pm 1.3$ & $1.2 \pm 0.9$ \\
\hline
\end{tabular}

1

2 


\section{Figure 1}

Figure 1: Map of Comau Fjord, located in North Patagonia, Los Lagos Region, Chile.

Shown are Huinay Scientific Field Station (Huinay) and the sampling sites Liliguapi and Cross Huinay. 


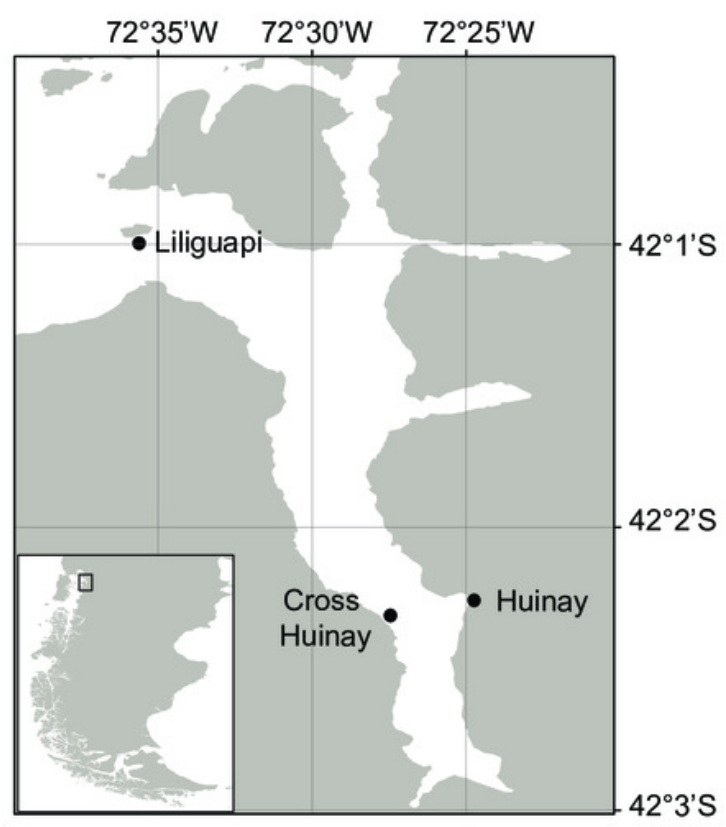




\section{Figure 2}

Conceptual carbon (C) and nitrogen (N) budget of the cold-water coral Desmophyllum dianthus.

The corals release parts of the taken-up $C$ and $N$ as organic matter (OM), i.e. particulate and dissolved organic carbon and nitrogen (POC, PON, DOC, DON), the remainder is assimilated ('Assimil.'). Parts of the assimilated $\mathrm{C}$ and $\mathrm{N}$ are lost during metabolism as carbon dioxide $\left(\mathrm{CO}_{2}\right)$ and ammonium $\left(\mathrm{NH}_{4}{ }^{+}\right)$, the remainder is invested in the growth of somatic and reproductive tissue and is termed scope for growth (SfG). The figure is modified from Soetaert \& van Oevelen (2009) and Warren \& Davis (1967). 


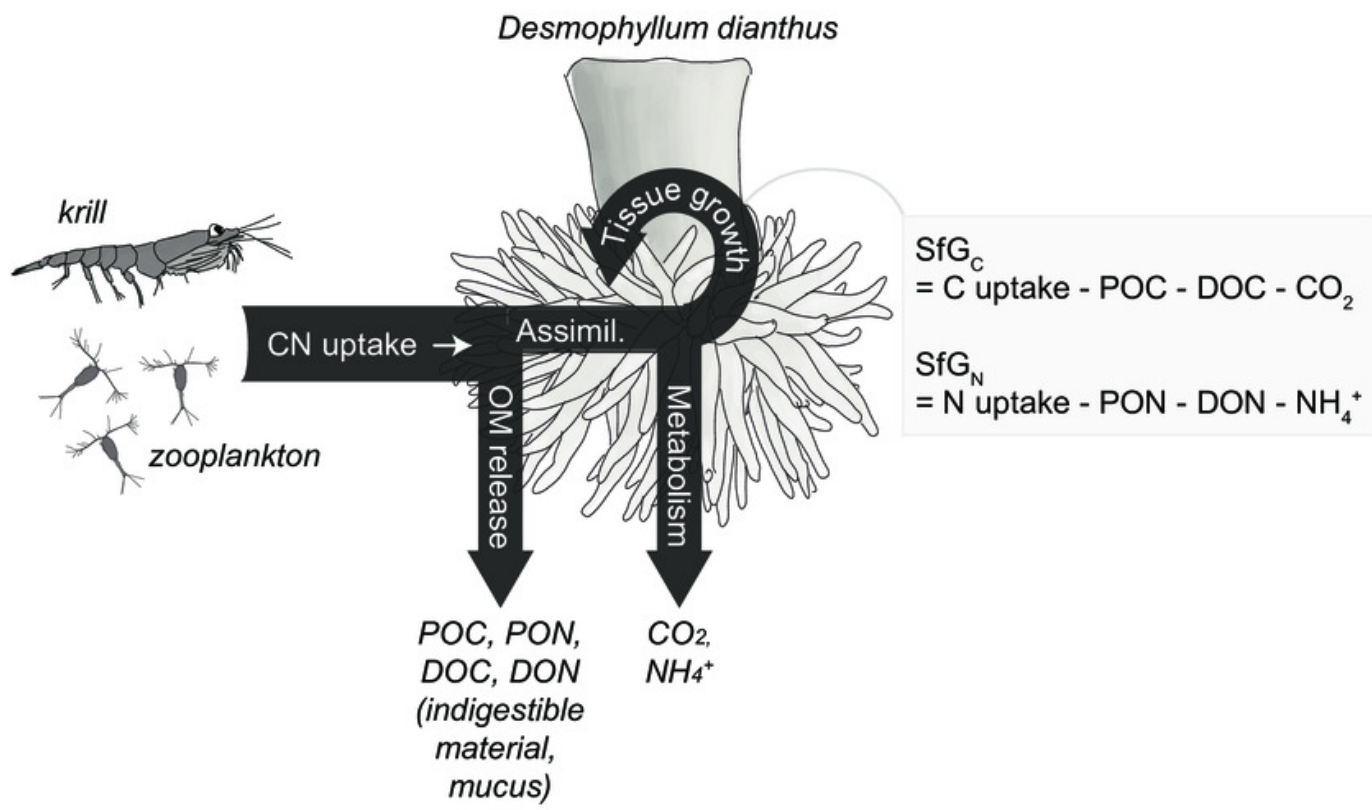




\section{Figure 3}

Coral maintenance, experimental set-up and measurements.

(A) Coral maintenance before and during the experiment. (B) Feeding treatments within the feeding scenarios 'zooplankton', 'zooplankton+krill', and 'unfed'. (C) Incubations following the feeding treatment in every feeding scenario. (B, C) Measurements at the start and end of the feeding/incubation are indicated. i.e. 'zoopl.': number of zooplankters in SCHOTT bottle; 'POC, PON': concentration of particulate organic carbon and nitrogen; 'krill CN': carbon and nitrogen content of krill; ' $\mathrm{O}_{2}$ ': oxygen concentration; 'DIN': concentration of dissolved inorganic nitrogen (ammonium, nitrate, nitrite); 'DOC, DON': concentration of dissolved organic carbon and nitrogen. 
a Coral maintenance

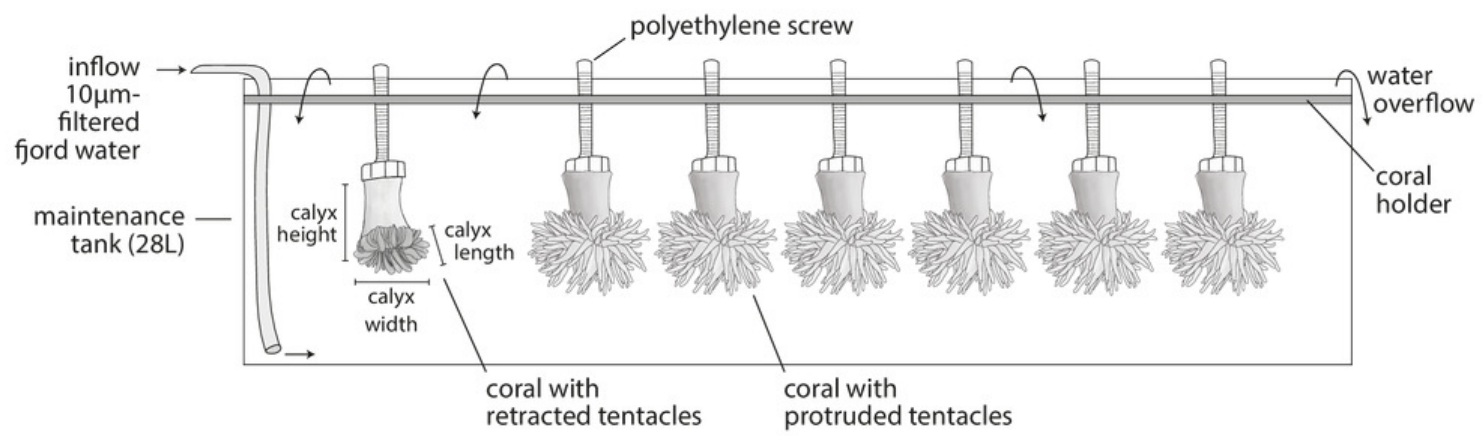

b Feeding treatments \& measurement of CN uptake

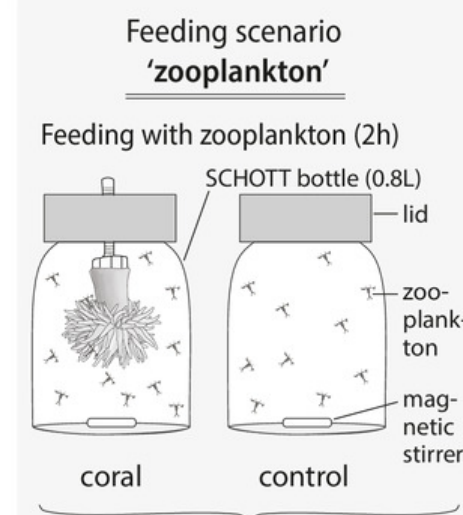

Measurement:

- start: ·POC, PON ·zoopl.

• end: ·POC, PON •zoopl.

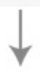

\section{c Incubations to measure $\mathrm{CN}$ loss}

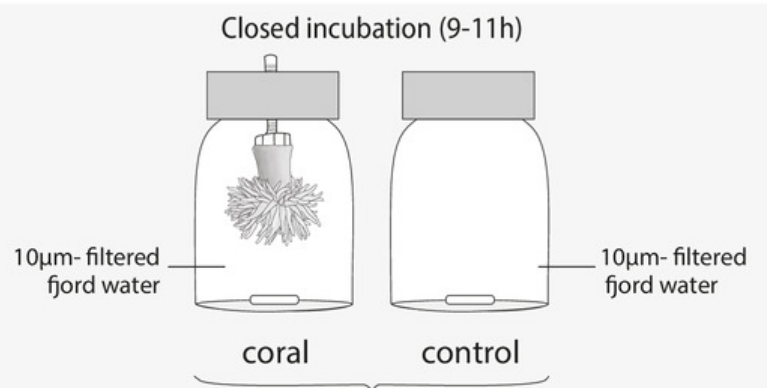

Measurement: • start: $\cdot \mathrm{O}_{2} \cdot \mathrm{DIN} \cdot \mathrm{DOC}, \mathrm{DON} \cdot \mathrm{POC}, \mathrm{PON}$

- end: $\cdot \mathrm{O}_{2} \cdot \mathrm{DIN} \cdot \mathrm{DOC}, \mathrm{DON} \cdot \mathrm{POC}, \mathrm{PON}$ 


\section{Figure 4}

Experimental design.

The $\mathrm{C}$ and $\mathrm{N}$ budget of Desmophyllum dianthus was determined in a two-batch repeatedmeasures laboratory experiment. Each of the two coral batches was exposed to two subsequent feeding scenarios, simulating the temporally variable food availability in Comau Fjord. Each feeding scenario started with a feeding treatment, during which we determined the $\mathrm{C}$ and $\mathrm{N}$ uptake of the corals. In a subsequent incubation without food, the $\mathrm{C}$ and $\mathrm{N}$ loss of the corals was measured. In addition to the coral feeding treatments and incubations, we carried out seawater controls without corals, to account for planktonic $\mathrm{C}$ and $\mathrm{N}$ fluxes (see text). The $\mathrm{C}$ and $\mathrm{N}$ budget of the corals was calculated for each feeding scenario, as the difference between $\mathrm{C}$ and $\mathrm{N}$ uptake and $\mathrm{C}$ and $\mathrm{N}$ loss. For the feeding scenario 'zooplankton + krill', two incubations were carried out; accordingly two $\mathrm{C}$ and $\mathrm{N}$ budgets were calculated. In between the feeding scenarios, corals were fed daily with zooplankton. 


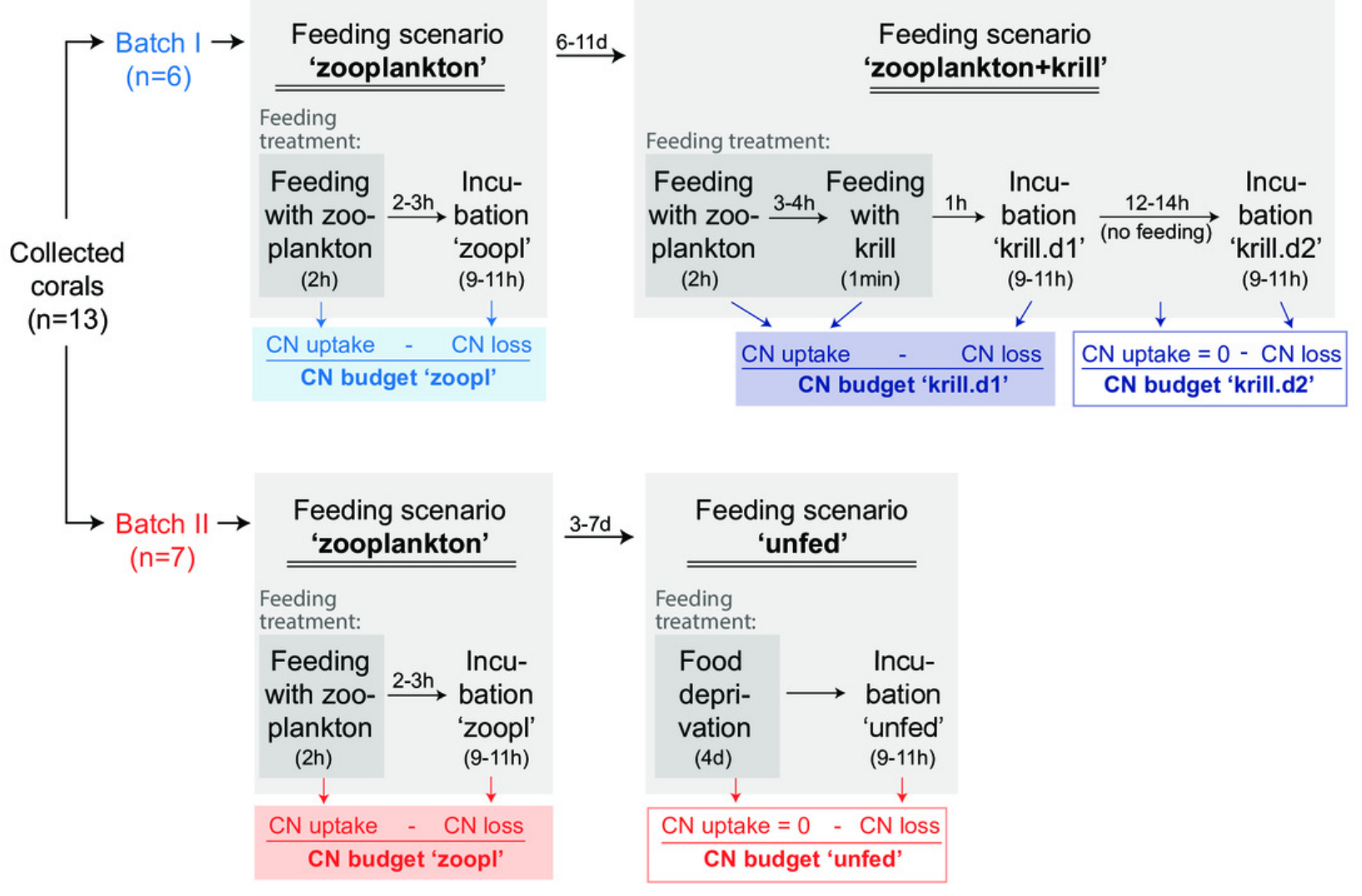




\section{Figure 5}

Carbon $(\mathrm{C})$ and nitrogen $(\mathrm{N})$ fluxes of Desmophyllum dianthus, exposed to different feeding treatments.

Feeding treatments were 'zoopl': fed with zooplankton; 'krill.d1': fed with zooplankton+krill, within the first day after feeding; 'krill.d2': fed with zooplankton+krill, $24 \mathrm{~h}$ after feeding; 'unfed': 4d-unfed. Blue colours: corals of batch I; red colours: corals of batch II. (A, B) $\mathrm{C}$ and $\mathrm{N}$ uptake during the feeding treatments; for 'unfed' and 'krill.d2', we assume no $\mathrm{C}$ and $\mathrm{N}$ uptake because corals were not fed for respectively four days and 24 hours; zero values represent six (open blue circles) and seven coral replicates (open red circles). (C$\mathrm{H}) \mathrm{C}$ and $\mathrm{N}$ loss measured in incubations after feeding: (C) respiration, (D) ammonium excretion, (E, F) release of particulate organic carbon and nitrogen (POC, PON), $(\mathrm{G}, \mathrm{H})$ release of dissolved organic carbon and nitrogen (DOC, DON). Bracket with *: linear mixed effect model found a significant difference between the indicated fluxes (see Supplemental Table 1.10 for details); ns: no significant difference. 

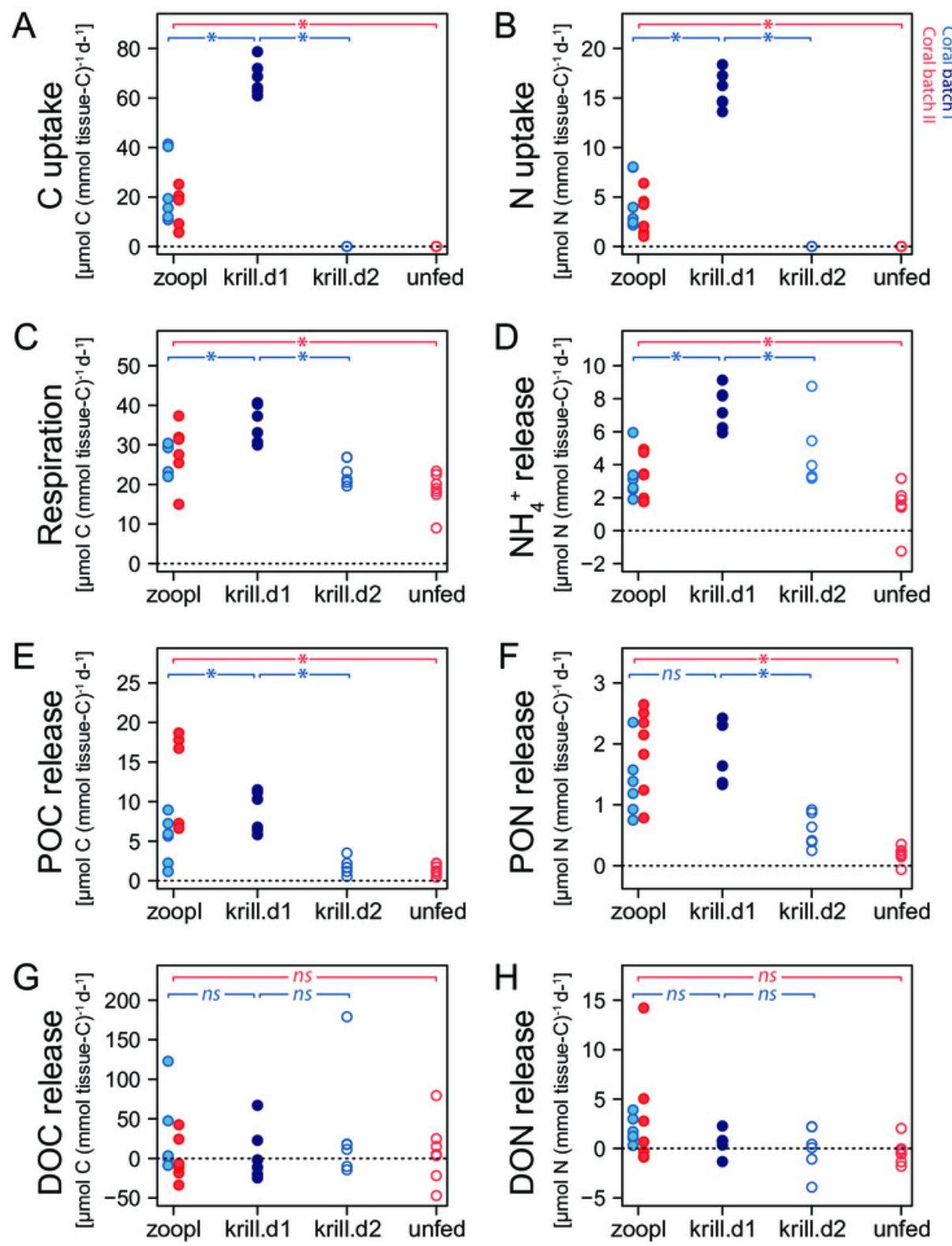


\title{
Figure 6
}

\section{Carbon (C) and nitrogen (N) budget of Desmophyllum dianthus exposed to different feeding treatments, as $\mathrm{C}$ or $\mathrm{N}$ loss versus $\mathrm{C}$ or $\mathrm{N}$ uptake.}

\begin{abstract}
(A) C budget, (B) N budget. Dotted line: Scope for growth $(\mathrm{SfG})=0$, i.e. $\mathrm{C}$ or $\mathrm{N}$ loss $=\mathrm{C}$ or $\mathrm{N}$ uptake. To the left of dotted line, marked in grey: SfG $<0$, i.e. $\mathrm{C}$ or $\mathrm{N}$ deficit, to the right of dotted line: $\mathrm{SfG}>0$, i.e. $\mathrm{C}$ or $\mathrm{N}$ surplus. Blue colours: corals of batch I; red colours: corals of batch II. Different symbols represent the different feeding treatments, as indicated in the legend, i.e. 'zoopl': fed with zooplankton, 'krill.d1': fed with zooplankton+krill, within the first day after feeding, 'krill.d2': fed with zooplankton+krill, $24 \mathrm{~h}$ after feeding, 'unfed': 4d-unfed. C loss includes $\mathrm{C}$ respiration and release of particulate organic carbon; $\mathrm{N}$ loss encompasses ammonium excretion and release of particulate organic nitrogen.
\end{abstract}



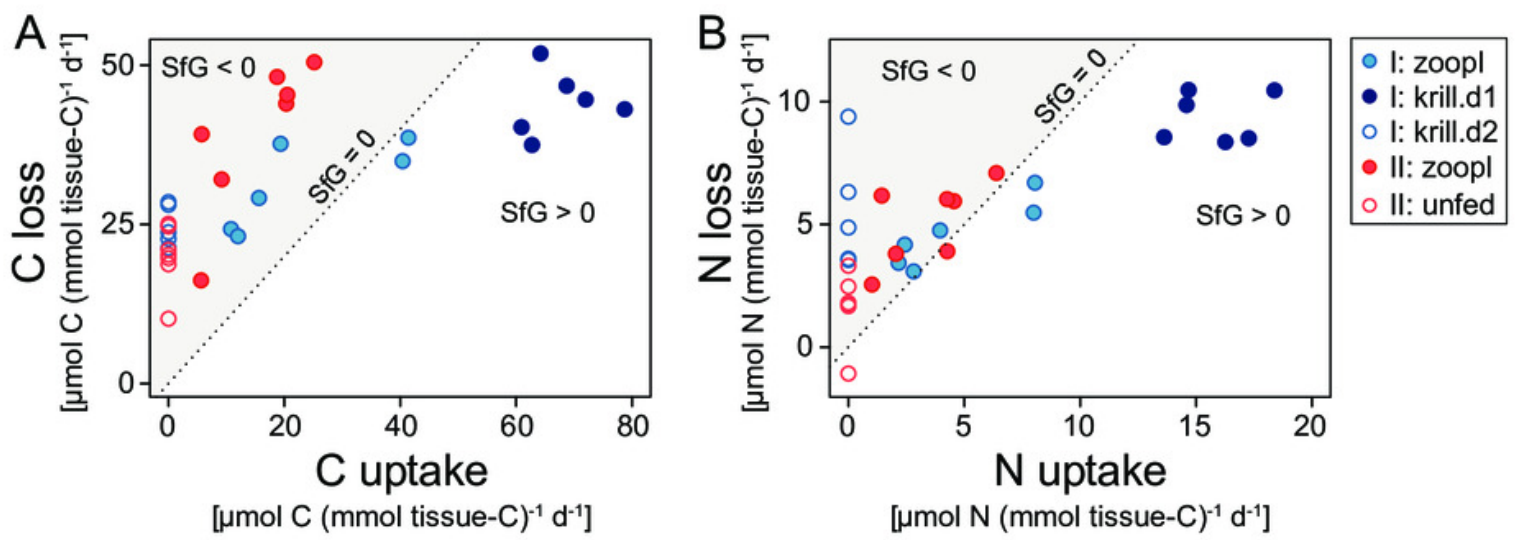


\section{Figure 7}

Dense swarms of krill and chaetognaths in Comau Fjord, directly above Desmophyllum dianthus.

Photo recorded by remotely-operated vehicle (C Richter) at $160 \mathrm{~m}$ depth. The arrow indicates one krill individual.

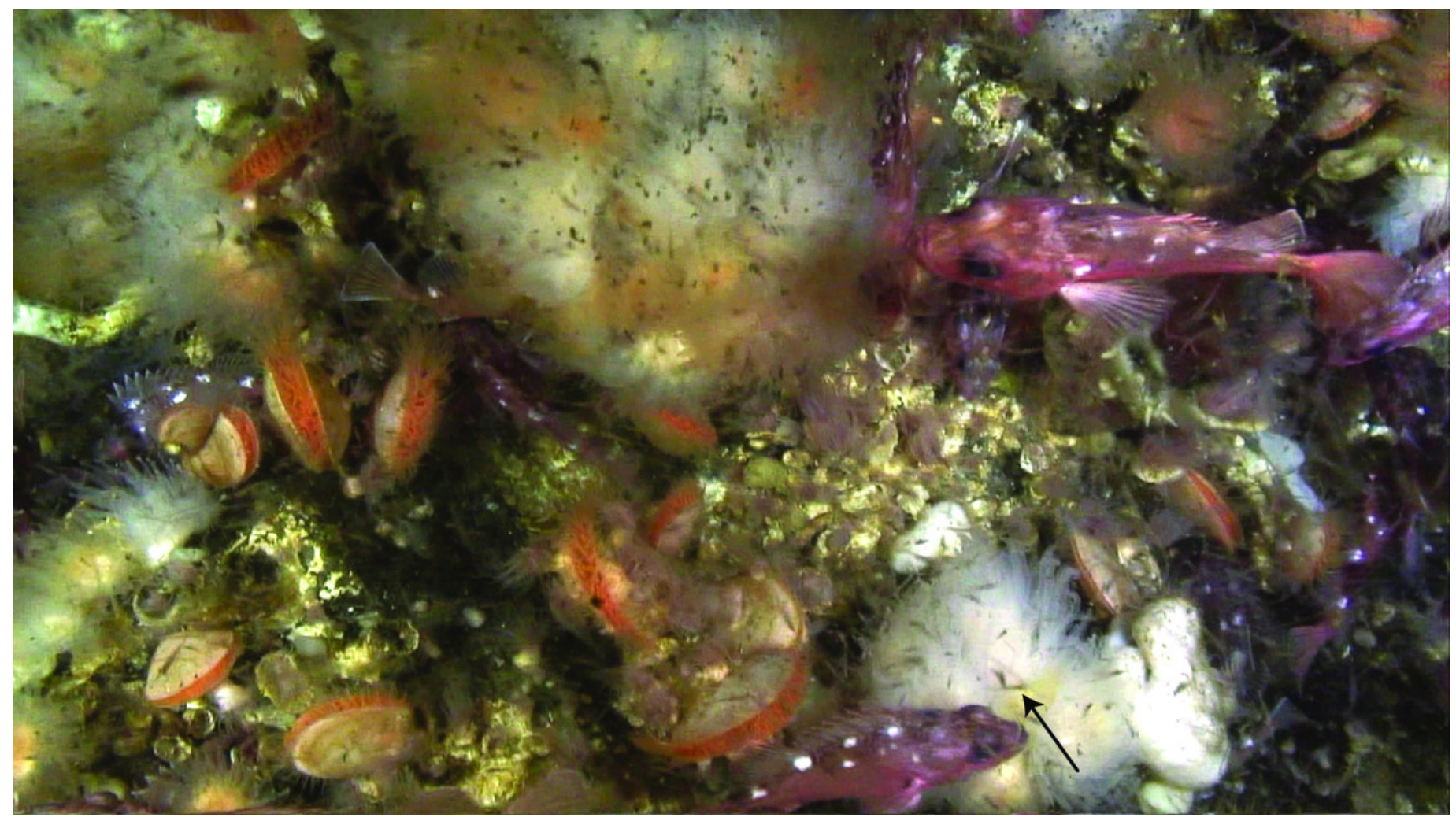

